Article

\title{
Isatin-1,8-Naphthalimide Hydrazones: A Study of Their Sensor and ON/OFF Functionality
}

\author{
Pavol Tisovský *®i, Miroslav Horváth, Klaudia Csicsai, Jana Donovalová, Juraj Filo®,

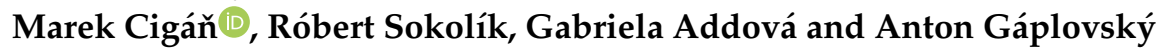

Faculty of Natural Sciences, Institute of Chemistry, Comenius University, Ilkovičova 6, Mlynská dolina CH-2, SK-842 15 Bratislava, Slovakia; mirek.horvath@gmail.com (M.H.); klaudia.jakusova@uniba.sk (K.C.); jana.donovalova@uniba.sk (J.D.); juraj.filo@uniba.sk (J.F.); marek.cigan@uniba.sk (M.C.); robert.sokolik@uniba.sk (R.S.); gabriela.addova@uniba.sk (G.A.) anton.gaplovsky@uniba.sk (A.G.)

* Correspondence: pavol.tisovsky@uniba.sk; Tel.: +421-2-60296-378

Received: 7 January 2019; Accepted: 19 January 2019; Published: 22 January 2019

\begin{abstract}
Five novel hydrazones derived from substituted isatins were synthesized as potential anion sensors. Using UV-VIS, FTIR, NMR and fluorescence spectroscopy, these compounds' tautomeric equilibrium and Z-E photoisomerization were studied in DMF and $\mathrm{CHCl}_{3}$, depending on the hydrazone concentrations, the presence of basic anions and light stimulation. Anion recognition aspects $\left(\mathrm{PF}_{6}{ }^{-}, \mathrm{HSO}_{4}{ }^{-}, \mathrm{Br}^{-}, \mathrm{Cl}^{-}, \mathrm{NO}_{3}{ }^{-}, \mathrm{F}^{-}\right.$and $\left.\mathrm{CH}_{3} \mathrm{COO}^{-}\right)$and these receptors' detection limits were also studied. We also tested the light-stimulated ON-OFF functionality of these compounds in the presence or absence of these anions.
\end{abstract}

Keywords: on/off switches; anion sensors; intramolecular interaction; UV-Vis spectroscopy

\section{Introduction}

Hydrazones belong to a group of chemical compounds whose photochromic properties are a prerequisite for their practical application as binary switches. From a practical point of view, they are very attractive molecules, with the switch function, where the light is used on its input and output. This type of molecules represents the simplest switch that can distinguish between two states: ON-OFF. To perform more complicated logic operations, it is necessary to provide a complex system. This system consisting of two or more suitably interconnected simple molecular switches either a system, which consists of one switch with multiple inputs and outputs. The photochromic molecules ability "to function" as molecular switches and to communicate with other chromophores create conditions for on Boolean's logic working photonic gates formation. In our previous works the isatin $N^{2}$-diarylhydrazone [1] or arylhydrazones [2,3] and their deprotonated forms were examined with the aim to use them as organic material for electronics or anion sensors. The UV-Vis spectra of these compounds are similar. Depending on the structure they have the absorption maximum in the wavelength range from $390 \mathrm{~nm}$ to $430 \mathrm{~nm}$. For all previously studied hydrazones, we have used their colorimetric properties or changes in their colorimetric parameters. Due to very small fluorescence quantum yield of these compounds the fluorescence was not used. Therefore, our goal was to prepare isatin hydrazones with sufficiently high fluorescence intensity and at the same time sufficiently large the fluorescence intensity change, as response to the stimulus. Naphthalimide is an easily modifiable structural fragment that is the part of many, more complex organic compounds and organic functional materials. For example, naphthalimide derivatives have been used as supramolecular units to study photo-induced electron transfer (PET) [4,5] as fluorescence bioprobes [6,7], laser dyes [8], fluorescence brighteners [9] and sensors [10-13]. Due to their high application potential, their photochemical and thermal stability was studied in detail [14-16]. 1,8-naphthalimide hydrazones 
are conjugated organic compounds with planar structure [17]. The 1,8-naphthalimide system is characterized by a strong positive quadrupole moment, that gives these molecules the opportunity to interact with anions through non-covalent anion- $\pi$ interaction [18]. Cheshmedzhieva et al. have found that 1,8-naphthalimide arylhydrazones with electron-donor groups increase fluorescence quantum yields [19]. Through these groups, it is possible to set up emission wavelengths up to the red spectrum range. The isatin hydrazone lowest excited state is $n-\pi^{*}$-electron state which-after its deactivation and photoisomerization - effectively competes with fluorescence [20]. Therefore, isatin hydrazones have very low fluorescence quantum yield. We tried to increase their excited state deactivation probability by fluorescence by introducing the 1,8-naphthalimide fragment into the isatin hydrazones structure. We prepared five new isatin 1,8-naphthalimide hydrazones.

\section{Results and Discussion}

\subsection{Synthesis}

Compounds 1-5 were prepared by condensation reaction of the corresponding isatin with hydrazine (Scheme 1).

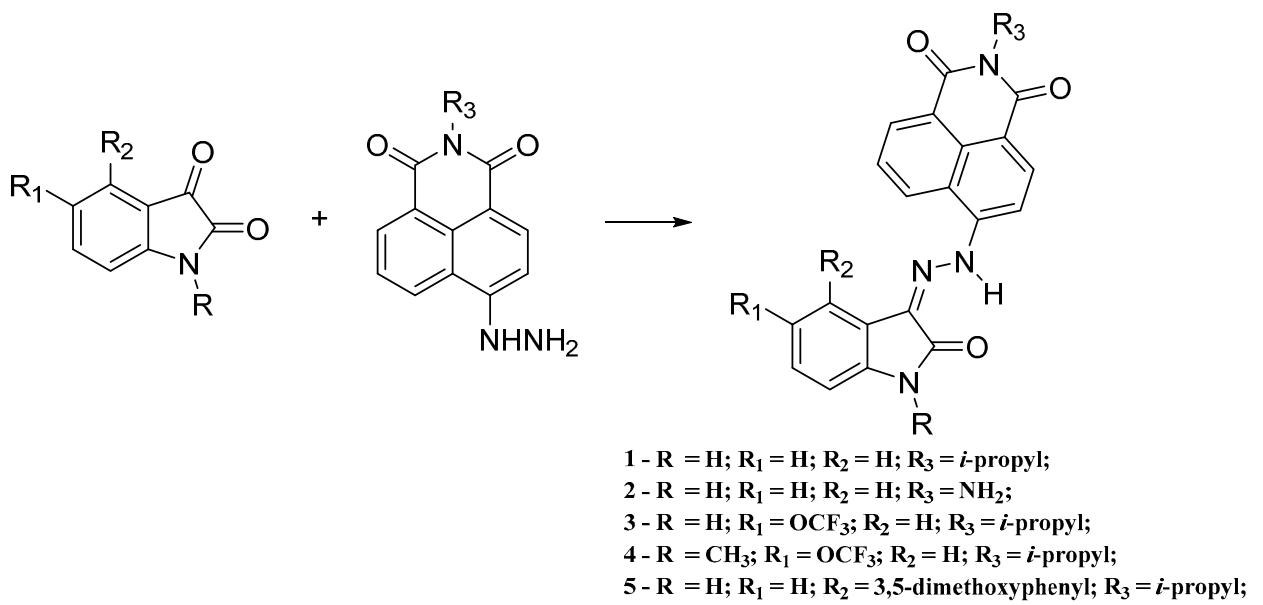

Scheme 1. Synthesis of compounds 1 to 5 .

The corresponding products were isolated in high yields (71-99\%). From the reaction mixture we isolated desired products with the Z-isomer configuration. Intramolecular hydrogen bond contributes to the $Z$-isomer stabilization. Compound $\mathbf{5}$ was designed so that the $E$-isomer was stabilized by the donor-acceptor interaction. Based on measurements, we found that by the synthesis the $E$-isomer was also formed. This isomer presence in the reaction mixture depends on the reaction conditions. In chloroform, the $E: Z$ ratio is even 1.5:1, what demonstrates, that $\mathrm{CT}$ (charge transfer) interaction increases the $E$-isomer stability.

\subsection{UV-VIS Spectra}

In the studied hydrazone molecules the 1,8-naphthalimide moiety electron deficient character is significantly affecting the charge distribution. It also appeared in the ultraviolet-visible (UV-Vis) spectra (Table 1). Compared to the isatin $N^{2}$-diaryl hydrazones or arylhydrazones these compounds have a long absorbent band, which is batochromically shifted at least about $30 \mathrm{~nm}$ [1,2]. The maximum band position is at $460 \mathrm{~nm}$ and depends a little on solvent polarity. These compounds also absorb in high dielectric constant solvents (dimethylformamide (DMF), dimethyl sulfoxide (DMSO)) in the range from $550 \mathrm{~nm}$ to $700 \mathrm{~nm}$ (Figure 1). In this spectrum region absorption bands are weak. Their intensity depends on their structure and hydrazone concentration. 
Table 1. Absorption and fluorescence maxima of isatin 1,8-naphthalimide hydrazones.

\begin{tabular}{|c|c|c|c|c|c|}
\hline \multirow{3}{*}{ Compound } & \multicolumn{3}{|c|}{ UV-VIS } & \multicolumn{2}{|c|}{ Fluorescence } \\
\hline & \multicolumn{2}{|c|}{ DMF } & \multirow{2}{*}{$\begin{array}{l}\mathrm{CHCl}_{3} \\
\lambda(\mathrm{nm})\end{array}$} & \multirow{2}{*}{$\begin{array}{c}\text { DMF } \\
\lambda(\mathrm{nm})\end{array}$} & \multirow{2}{*}{$\begin{array}{l}\mathrm{CHCl}_{3} \\
\lambda(\mathrm{nm})\end{array}$} \\
\hline & $\lambda_{1}(\mathrm{~nm})$ & $\lambda_{2}(\mathrm{~nm})$ & & & \\
\hline $1 \mathrm{Z}$ & 463 & 634 & 464 & $\begin{array}{l}\text { 532/exc. } 465 \\
686 / \text { exc. } 630\end{array}$ & $\begin{array}{l}533 / \text { exc. } 465 \\
\text {-/еxc. } 630\end{array}$ \\
\hline $2 \mathrm{Z}$ & 468 & 645 & 468 & 553/exc.465 & -/exc.465 \\
\hline $3 \mathrm{Z}$ & 462 & 625 & 464 & $\begin{array}{l}544 / \text { exc. } 465 \\
688 / \text { exc. } 630\end{array}$ & $\begin{array}{l}564 / \text { exc. } 465 \\
687 / \text { exc.630 }\end{array}$ \\
\hline $4 \mathrm{Z}$ & 460 & 625 & 464 & $\begin{array}{l}537 / \text { exc. } 465 \\
687 / \text { exc. } 630\end{array}$ & $\begin{array}{l}556 / \text { exc. } 465 \\
-/ \text { exc.630 }\end{array}$ \\
\hline $5 \mathrm{Z}$ & 474 & $650 *$ & $468486^{* *}$ & $\begin{array}{l}532 / \text { exc. } 465 \\
-/ \text { exc.630 }\end{array}$ & $\begin{array}{c}537,558 * * / \text { exc. } 465 \\
\text {-/exc. } 630\end{array}$ \\
\hline
\end{tabular}

$\lambda_{1}$-short-wavelength absorption maximum; $\lambda_{2}$-long-wavelength absorption maximum; ${ }^{*}$ very weak, ${ }^{* *}$ shoulder.

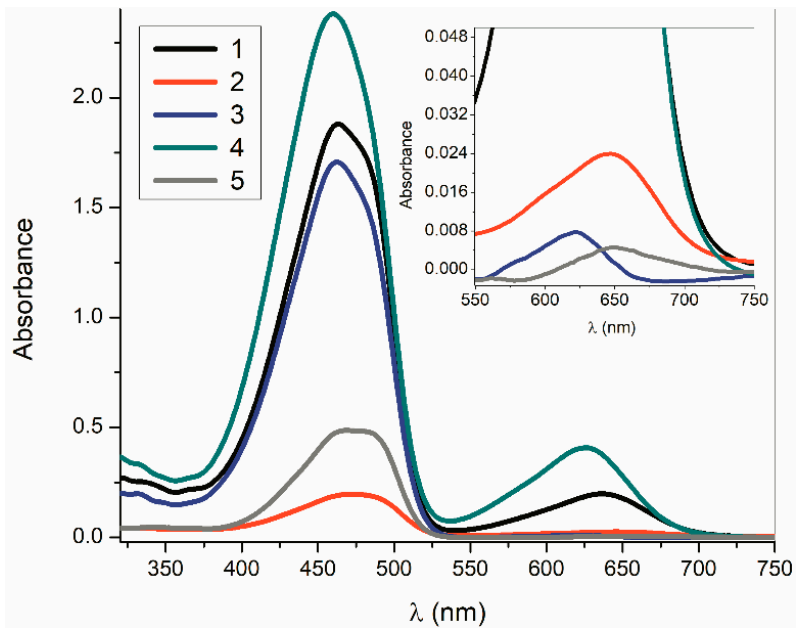

Figure 1. The studied isatin hydrazones 1, 3-5 $\left(5 \times 10^{-5} \mathrm{~mol} . \mathrm{dm}^{-3}\right)$ and $\mathbf{2}$ (saturated solution) UV-Vis spectra in DMF.

With an increasing hydrazone concentration, the band intensity decreases at $630 \mathrm{~nm}$ and at the same time the band intensity increases at $460 \mathrm{~nm}$ (Figure 2). Concentration dependence confirms the donor-acceptor intermolecular interactions existence that contribute to the hydrazone structure stabilization [21].

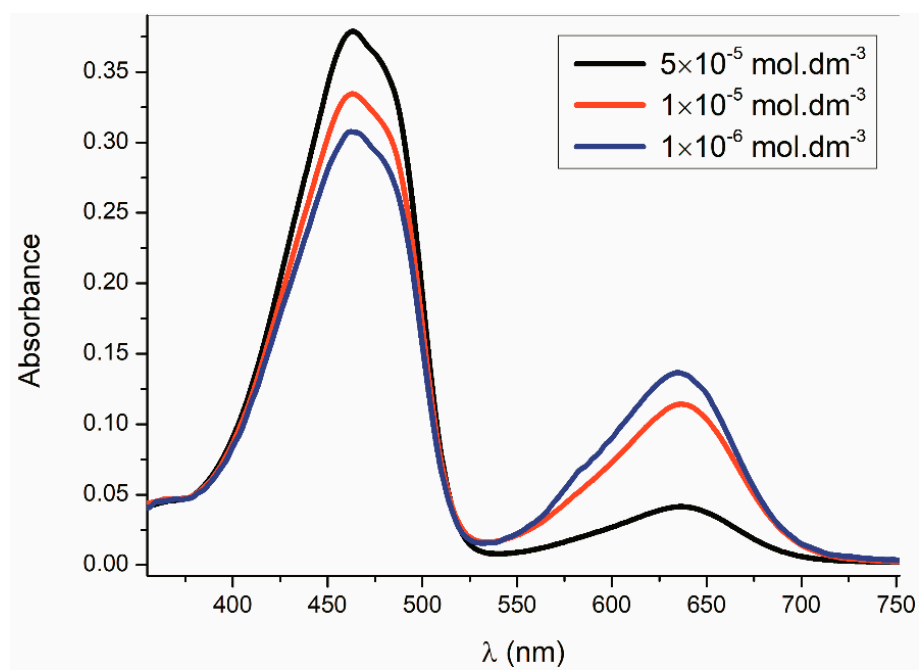

Figure 2. Hydrazone 1 UV-Vis spectra concentration dependence in DMF (recalculated). 


\subsection{Tautomeric Equilibrium Z-E and E-Z Isomerization}

The absorption maxima ratio reversible temperature dependency at $460 \mathrm{~nm}$ and $630 \mathrm{~nm}$ (Figure 3) confirms the chemical equilibrium existence between the hydrazone and the substance, that absorbs at $630 \mathrm{~nm}$. The UV-Vis spectra concentration dependence was observed, e.g., at 3-(2-phenylhydrazono)indolin-2-one, too [2].
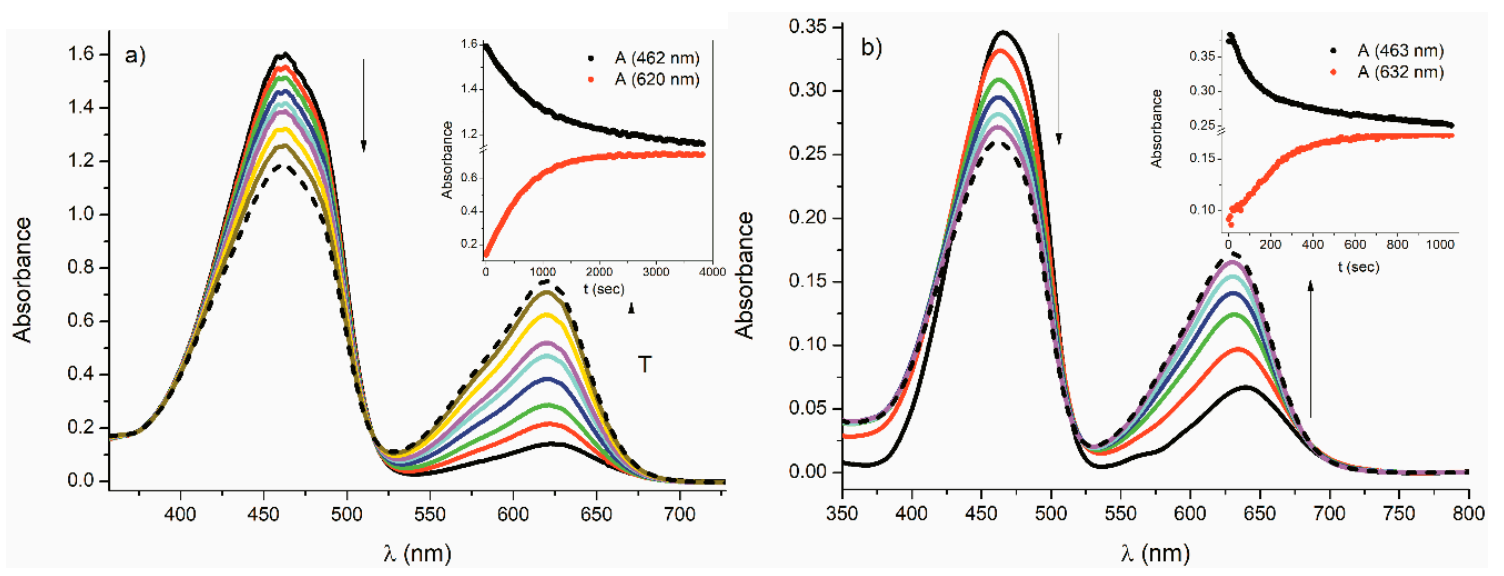

Figure 3. UV-Vis spectra change: (a) hydrazone $3\left(5 \times 10^{-5}\right.$ mol.dm $\left.{ }^{-3}\right)$ at temperature $50{ }^{\circ} \mathrm{C}$ and (b) hydrazone $1\left(10^{-5} \mathrm{~mol} . \mathrm{dm}^{-3}\right)$ at temperature $80^{\circ} \mathrm{C}$ as the time function in DMF (in set: kinetic course of reaction isothermal change).

In these works [2,3], we have shown that the lowest energy band resulting from the hydrazone concentration decreasing, arises because of the cyclic hydrogen bond disappearance between two isatin hydrazone moieties. In the case of isatin 1,8-naphthylimide hydrazones this was not observed. The isatin NH hydrogen substitution for the methyl group, does not prevent of the band formation at $630 \mathrm{~nm}$. Methylation leads to increase of the band intensity at $630 \mathrm{~nm}$ as compared to an analogous non-methylated compound (Figure 4a,b) $160 \mathrm{~nm}$ difference in the hydrazones between $\mathbf{B}$ maximum positions (about $460 \mathrm{~nm}$ ) and the form that absorbs at $630 \mathrm{~nm}$ indicates the large charge transfer in the molecule (Scheme 2).
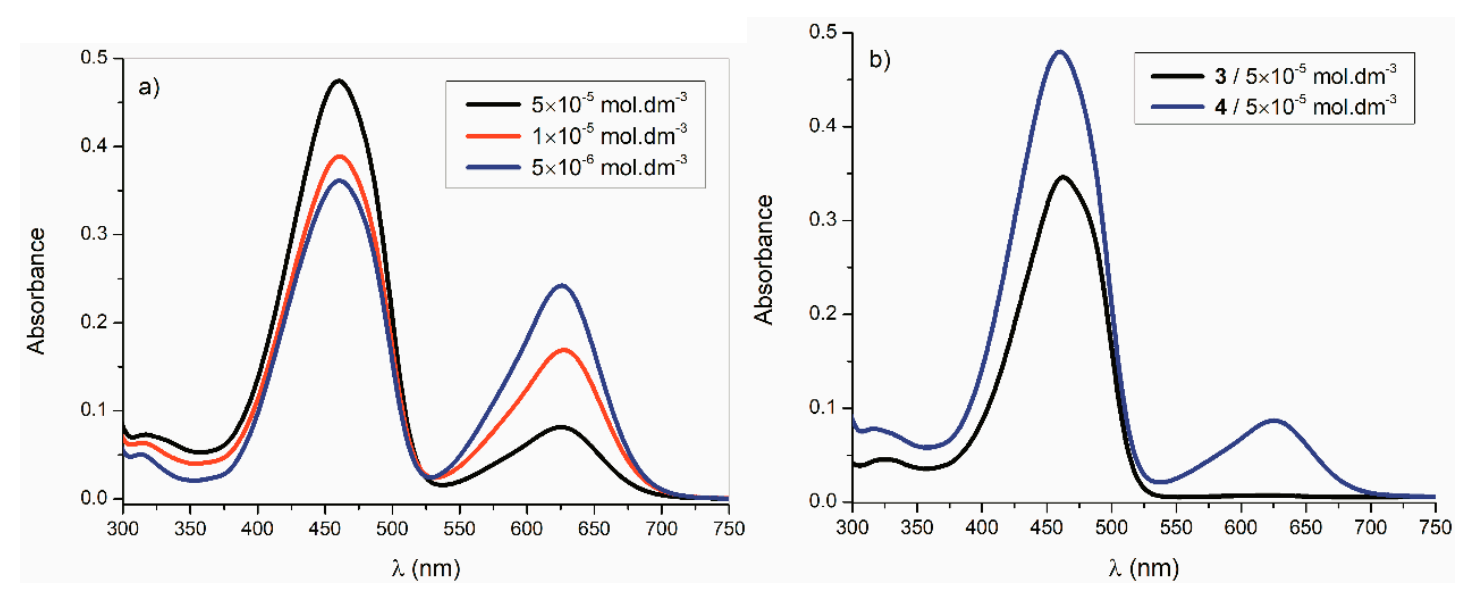

Figure 4. Hydrazone 3 and 4 UV-Vis spectra in DMF, (recalculated). (a) hydrazone 4 the concentration effect; (b) the isatin methylation effect on the UV-Vis spectrum. 


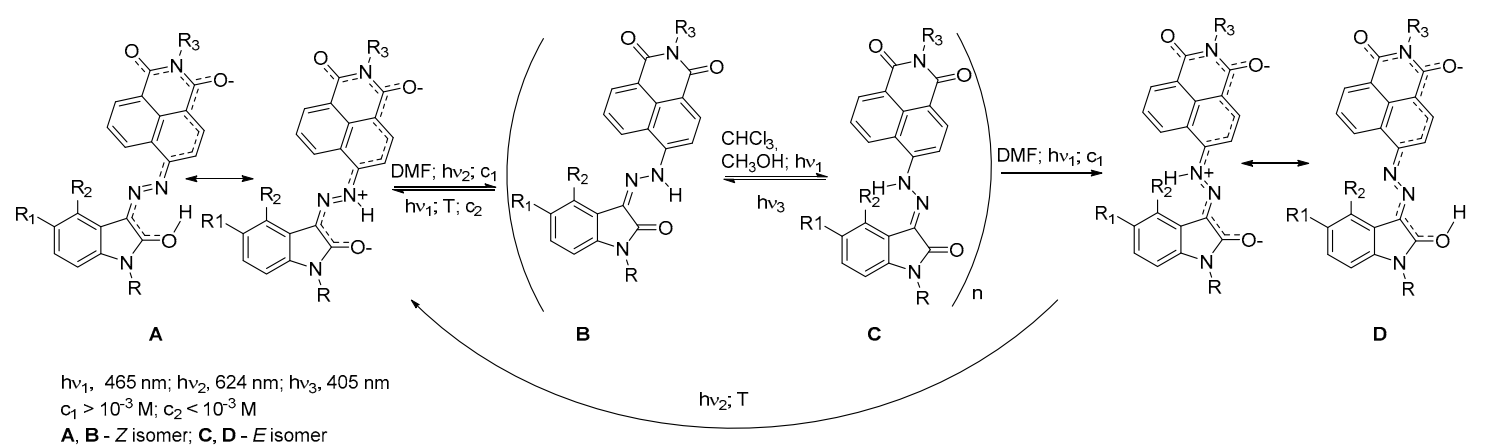

Scheme 2. The hydrazone concentration, light, temperature and solvent polarity effect on the studied compounds equilibrium reactions.

We assigned structures $\mathbf{A}$ and $\mathbf{D}$ to the compound absorbing in UV-Vis spectra at $630 \mathrm{~nm}$. These structures are stabilized by aprotic solvents with the sufficiently high dielectric constant (e.g., DMSO, DMF, acetonitrile). This conclusion is consistent with spectral measurements as well as with the theoretical calculations results [22]. The structures $\mathbf{A}$ and $\mathbf{D} \mathbf{C}=\mathrm{N}$ charge density is lower than the $\mathbf{B}$ and $\mathbf{C}$. Intramolecular hydrogen bond also disappeared in the structure $\mathbf{D}$. Extinction or weakening of an intramolecular molecular hydrogen bond, the stability of the molecule $\mathbf{D}$ decreases that-after irradiation with the light $465 \mathrm{~nm}$ or with the temperature-it changes to structure A. This was proved by ${ }^{1} \mathrm{H}-\mathrm{NMR}$ and High-performance liquid chromatography (HPLC). In nonpolar $\left(\mathrm{CHCl}_{3}\right)$ and polar protic solvents $\left(\mathrm{CH}_{3} \mathrm{OH}\right)$, structures $\mathbf{A}$ and $\mathbf{D}$ do not form, respectively, if they form, their concentration is below the used spectral methods detection limit. After studied hydrazones irradiation in these solvents, the hydrazones typical photochemical reaction i.e., the reversible geometric isomerisation around the $\mathrm{C}=\mathrm{N}$ bond occurs (Figure 5; supplementary Figures S1 and S2). The $E$ and $Z$ studied compound isomers UV-Vis spectra show a slight difference. From Figure 6, is evident that during the $Z \leftrightarrows E$ isomerisation, the new bands at the higher frequencies corresponding to the $E$-isomer are formed in spectrum of compound 4 in the carbonyl region in the Fourier transform infrared spectra (FTIR). This is mainly caused by the intramolecular hydrogen bond disappearance in the molecule and the $E$ isomer planarity decreases.

In Table 2. are shown the $Z$ and $E$ isomer relative abundance in the equilibrium state after $Z$-isomer $\left(5 \times 10^{-5} \mathrm{~mol} \cdot \mathrm{dm}^{-3}\right)$ irradiation with $465 \mathrm{~nm}$ in $\mathrm{CHCl}_{3}$ and DMF (determined by HPLC).

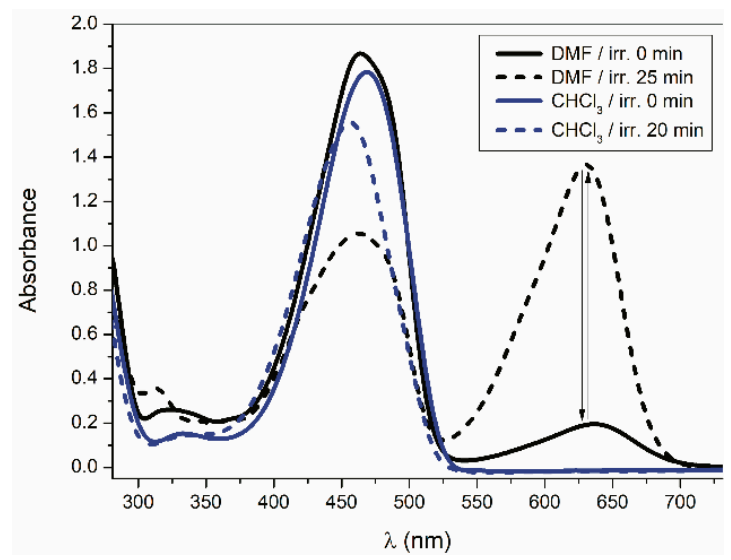

Figure 5. Compound $1 \mathrm{UV}$-Vis spectra change in DMF and $\mathrm{CHCl}_{3}\left(5 \times 10^{-5}\right.$ mol.dm $\left.{ }^{-3}\right)$ during irradiation with wavelength $465 \mathrm{~nm}$. 


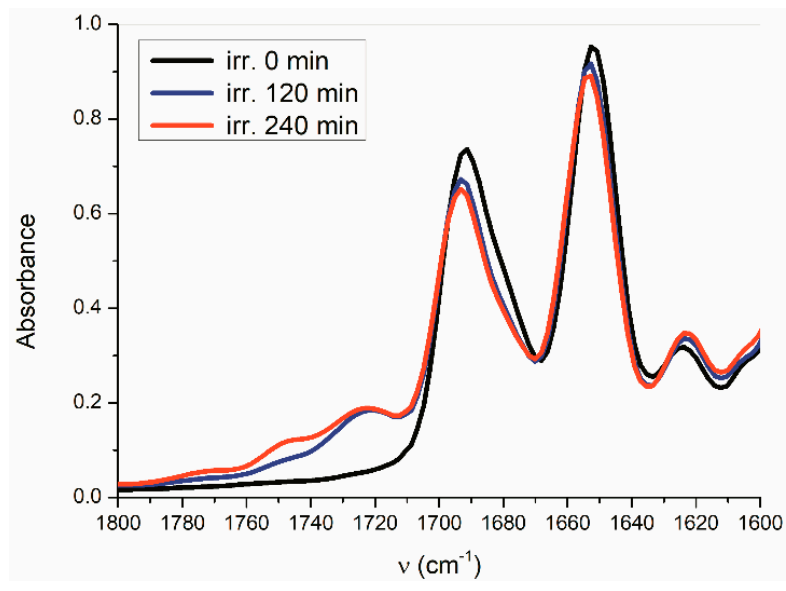

Figure 6. Compound $4\left(1 \times 10^{-3}\right.$ mol.dm $\left.{ }^{-3}\right)$ FTIR spectra during irradiation $(\lambda=525 \mathrm{~nm})$ in $\mathrm{CHCl}_{3}$.

Table 2. The studied hydrazones $Z$ and $E$ isomers proportional representation in the equilibrium mixture after $Z$-isomers photolysis $(465 \mathrm{~nm})$ in $\mathrm{CHCl}_{3}$ and $\mathrm{DMF}$ determined by HPLC.

\begin{tabular}{ccc}
\hline \multirow{2}{*}{ Compound } & $\mathrm{CHCl}_{\mathbf{3}}$ & $\mathrm{DMF}$ \\
\cline { 2 - 3 } & $\mathbf{Z} / \mathbf{E}$ & $\mathbf{Z} / \mathbf{E}$ \\
\hline $\mathbf{1}$ & 1.1 & 3.5 \\
$\mathbf{3}$ & 3.3 & 5.9 \\
$\mathbf{4}$ & 16.2 & 18.1 \\
$\mathbf{5}$ & 1.9 & 11.4 \\
\hline \multicolumn{3}{c}{ Compound 2 was not soluble enough. }
\end{tabular}

At all the studied compounds in $\mathrm{CHCl}_{3}$ the $E$-isomer abundance in the photostationary state depends on their coefficients $\varepsilon_{\lambda \text { irr }}$ differences corresponding to the $E$ and $Z$ isomers. From the data in Table 2 for the $Z$-isomers irradiation is evident that even in DMF, $E$-isomers are formed, however, the $E$-isomer ratio is low compared to that in $\mathrm{CHCl}_{3}$. This is due to either thermal and photochemical stability or $\mathbf{A}$ and $\mathbf{D}$ reactivity (Scheme 2). For this reason, the E-isomer abundance is low, in the studied hydrazones synthesis in aprotic solvents with a high dielectric constant. This was confirmed in the compound 5 synthesis in DMF where the $E$-isomer abundance was negligible but in $\mathrm{CHCl}_{3}$ it was up to $\sim 60 \%$. Different photoreactivity in $\mathrm{DMF}$ and $\mathrm{CHCl}_{3}$ can be seen very well in Figure 7 . In hydrazones UV-VIS spectra in polar aprotic solvents (DMF, DMSO) during irradiation (465 nm), was observed the band formation at $630 \mathrm{~nm}$ (Figures 5 and 7; supplementary Figure S3).

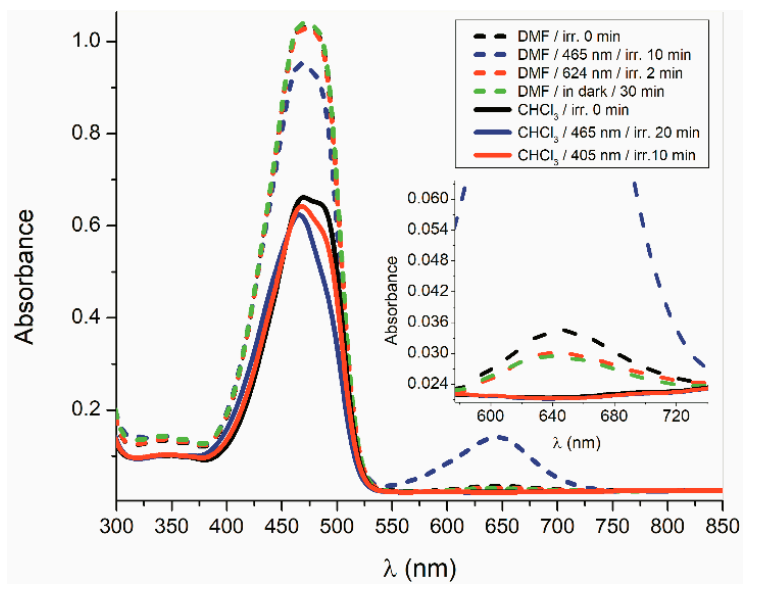

Figure 7. Compound $5\left(1 \times 10^{-4} \mathrm{~mol} \cdot \mathrm{dm}^{-3}\right)$ UV-Vis spectra change during photochemical isomerisation in DMF and $\mathrm{CHCl}_{3}$. 
This band is the same as it was observed at the described concentration dependence. The change in UV-Vis spectra is reversible. Using light with $\lambda>520 \mathrm{~nm}$ band intensity at $630 \mathrm{~nm}$ decreases with the simultaneous band intensity increase at $460 \mathrm{~nm}$ (Figure 8; supplementary Figure S3).

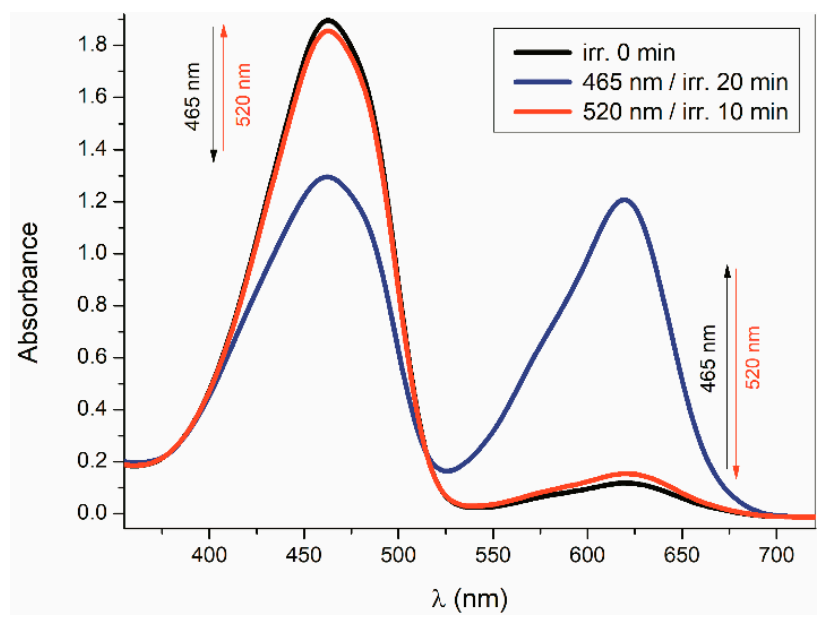

Figure 8. Compound $3\left(1 \times 10^{-4} \mathrm{~mol} \cdot \mathrm{dm}^{-3}\right) \mathrm{UV}$-Vis spectra change during irradiation, alternating by turns with different wavelength lights (465 $\mathrm{nm}$ a $624 \mathrm{~nm}$ ) in DMF.

Compared to other isatin arylhydrazones the 1,8-naphthylimide fragment presence in the studied hydrazones increased their fluorescence quantum yields. For compound $\mathbf{1}$ the highest fluorescence quantum yield in DMF and methanol was observed (Table 3). The tautomeric equilibrium existence was also confirmed by fluorescence measurements (Figure 9). We also observed two fluorescence bands dependent on the excitation wavelength $(460 \mathrm{~nm}$ and $630 \mathrm{~nm})$. One at $\lambda_{\text {exc. }}=460 \mathrm{~nm}$ with the maximum fluorescence around $550 \mathrm{~nm}$ (hydrazone form $\mathbf{B}$ or $\mathbf{C}$ ) and the other at $\lambda_{\text {exc. }}=630 \mathrm{~nm}$ with the maximum around $690 \mathrm{~nm}$ (tautomeric form A and D) (Scheme 2). The both maxima positions relatively slightly depend on the hydrazones structure and on the solvent polarity (Table 1). Both fluorescent bands are the corresponding absorbent band mirror image (Figure 9). The fluorescence intensity at $550 \mathrm{~nm}$ in $\mathrm{CHCl}_{3}$ and DMF is concentration dependent (Figure 10).
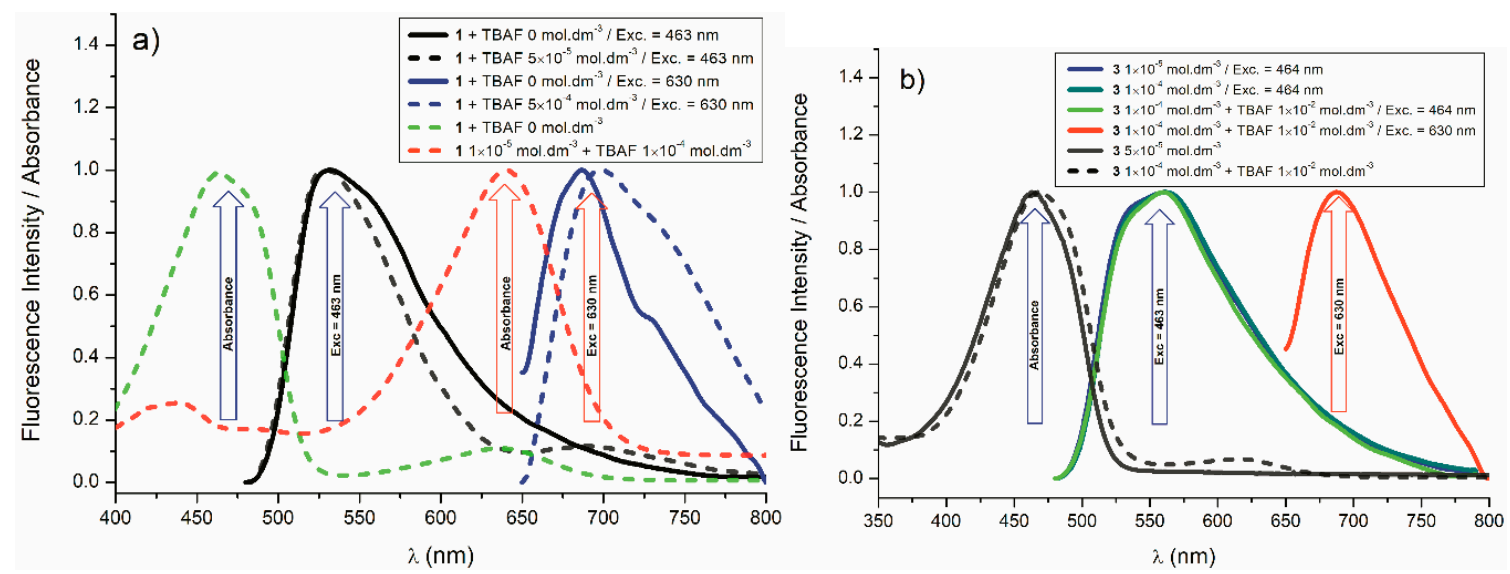

Figure 9. Normalized fluorescence and absorption spectra (a) hydrazone 1 (DMF) (b) hydrazone 3 $\left(\mathrm{CHCl}_{3}\right)$ in the presence and absence of $\mathrm{F}^{-}$ions. 

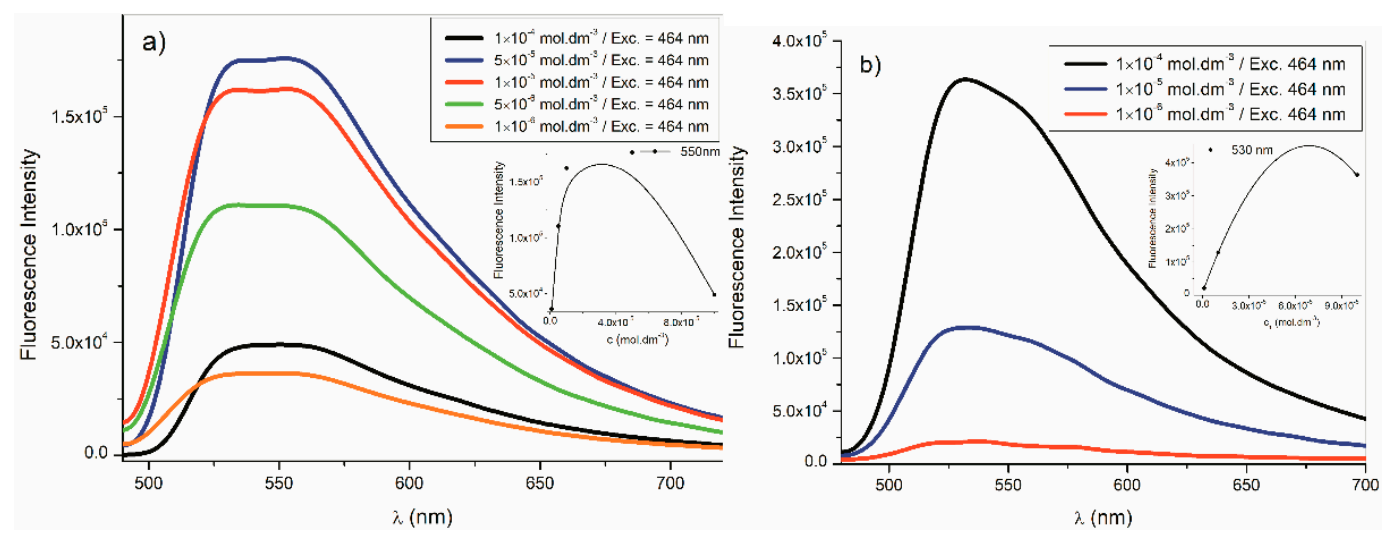

Figure 10. Concentration fluorescence quenching of hydrazone 1, (a) in $\mathrm{CHCl}_{3}$, (b) in DMF after excitation $\lambda_{\text {exc. }}=464 \mathrm{~nm}$.

Table 3. Quantum yields and 1,8-naphthalimide hydrazone fluorescence lifetimes; $\chi^{2}$ —reduced chi-square.

\begin{tabular}{|c|c|c|c|c|c|c|c|c|c|}
\hline Compound & & $\Phi_{\mathrm{F}}$ & $\tau_{1}[\mathrm{~ns}]$ & $\%$ & $\tau_{2}[\mathrm{~ns}]$ & $\%$ & $\tau_{3}[\mathrm{~ns}]$ & $\%$ & $x^{2}$ \\
\hline \multirow[t]{3}{*}{1} & DMF & 0.04 & 0.028 & 23.5 & 3.41 & 48.9 & 9.02 & 27.6 & 1.3 \\
\hline & $\mathrm{CHCl}_{3}$ & - & 0.06 & 76.9 & - & - & 7.44 & 23.1 & 1.34 \\
\hline & $\mathrm{CH}_{3} \mathrm{OH}$ & 0.03 & 0.04 & 53.7 & 3.7 & 15.7 & 9.03 & 30.6 & 1.4 \\
\hline \multirow[t]{2}{*}{2} & DMF & $<0.01$ & 0.04 & 37 & 3.2 & 52.5 & 10.6 & 10.5 & 1.13 \\
\hline & $\mathrm{CH}_{3} \mathrm{OH}$ & $<0.01$ & 0.08 & 27.3 & 0.98 & 33.5 & 6.1 & 39.1 & 1.26 \\
\hline \multirow[t]{3}{*}{3} & DMF & $<0.01$ & 0.03 & 20.1 & 3.51 & 13.3 & 8.78 & 66.6 & 1.48 \\
\hline & $\mathrm{CHCl}_{3}$ & - & 0.1 & 59.1 & - & - & 8.9 & 40.9 & - \\
\hline & $\mathrm{CH}_{3} \mathrm{OH}$ & $<0.01$ & 0.14 & 61.2 & 2.87 & 8.1 & 8.88 & 30.7 & 1.16 \\
\hline \multirow[t]{5}{*}{4} & DMF & $<0.01$ & 0.12 & 7.1 & 4.73 & 24.7 & 9.16 & 68.2 & 1.03 \\
\hline & $\mathrm{CH}_{3} \mathrm{OH}$ & 0.03 & 0.25 & 19.9 & 3.42 & 18.9 & 7.89 & 61.2 & 1.26 \\
\hline & DMF & $<0.01$ & 0.07 & 32.3 & - & - & 8.2 & 63.7 & 1.16 \\
\hline & $\mathrm{CHCl}_{3}$ & - & 0.28 & 93.4 & - & - & 8.3 & 6.6 & - \\
\hline & $\mathrm{CH}_{3} \mathrm{OH}$ & 0.02 & 0.12 & 73.4 & - & - & 7.5 & 26.6 & 1.18 \\
\hline
\end{tabular}

$\Phi_{\mathrm{F}}$-Fluorescence quantum yield; $\tau$-Fluorescence lifetime; $\chi 2$-Quality of fluorescence lifetime fiting;. \%-relative fluorescence intensity of the corresponding component. 
In DMF is the concentration quenching less effective. In both solvents this concentration quenching is probably caused by intermolecular Coulombic interactions that stabilize the hydrazone form B or C (Scheme 2). The concentration changes influences fluorescence spectra at $\lambda_{\text {exc. }}=465 \mathrm{~nm}$ and UV-Vis spectra in the same way.

Fluorescence at $690 \mathrm{~nm}$ (tautomeric form D or A) varies linearly and is not influenced by concentration quenching (Figure 11). Tautomeric equilibrium changes and the $\mathrm{F}^{-}$ions effect on it can also be monitored by excitation spectra (Figure 12).

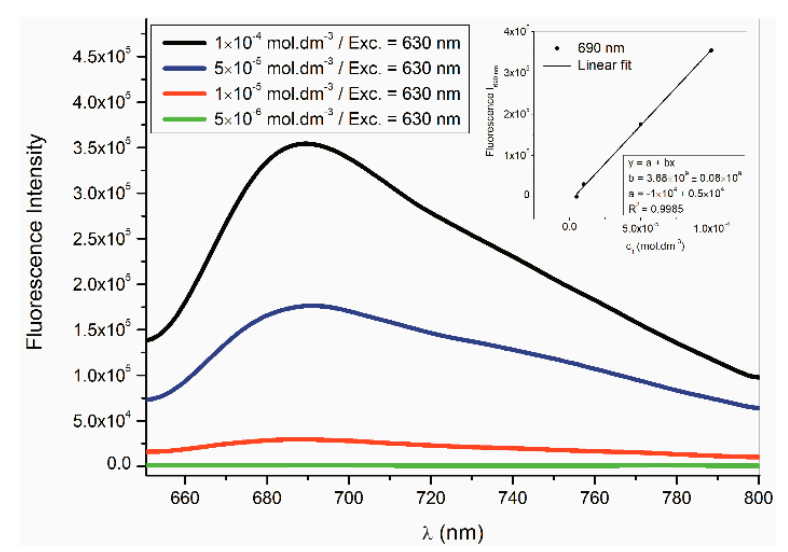

Figure 11. Compound 1 fluorescence intensity change with the concentration change at excitation $630 \mathrm{~nm}$ in DMF.
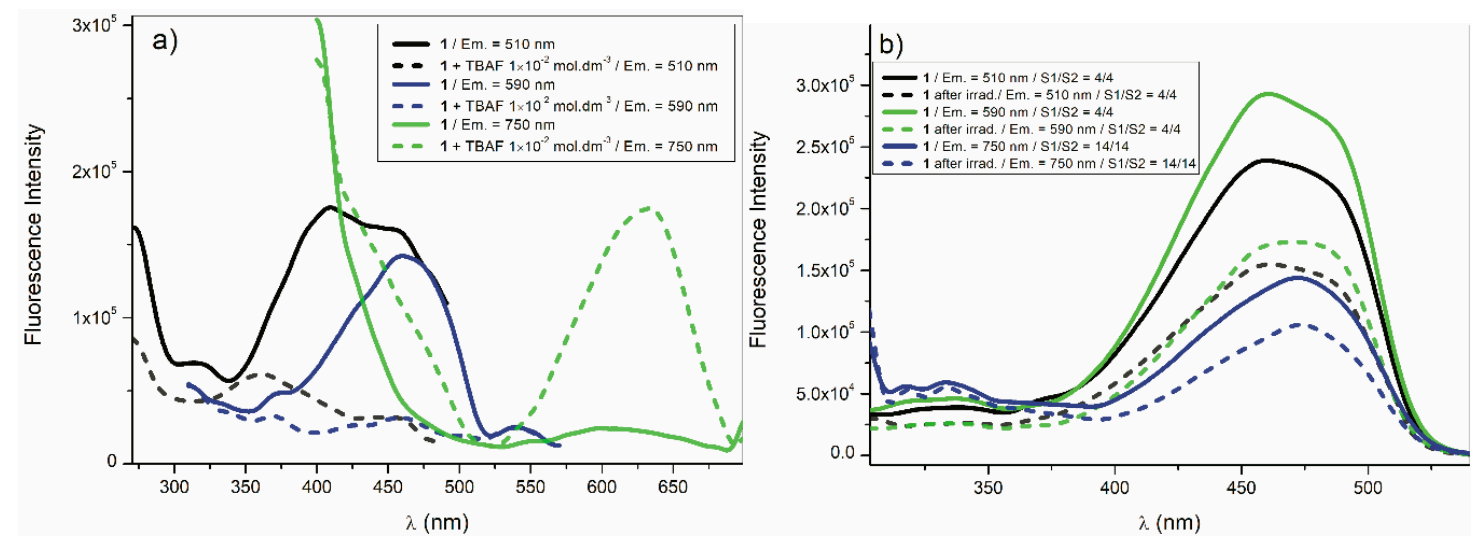

Figure 12. Excitation spectra non-irradiated and irradiated $\left(\lambda_{\text {exc. }}=465 \mathrm{~nm}\right)$ compound 1 in (a) DMF and (b) $\mathrm{CHCl}_{3}\left(\lambda_{\mathrm{em} .}=510 \mathrm{~nm}, 590 \mathrm{~nm}\right.$ and $\left.750 \mathrm{~nm}\right)$.

In the spectral region from 350 to $525 \mathrm{~nm}$ using the excitation spectra, rather than the UV-Vis spectra in DMF it is possible to distinguish the individual compounds involved in the equilibrium state. This change is likely corresponding to the geometric changes in the hydrazone molecule. We obtained three fluorescence lifetimes by mathematical fitting of the fluorescence lifetime curve (by three-exponential function). From the data in Table 3 and Figure 1 is evident the correlation between the electronic states abundance with lifetime $\tau_{2}$ percentage the studied hydrazone tautomeric forms A or D abundance in DMF (Scheme 2).

After excitation at $630 \mathrm{~nm}$ we did not observe this tautomeric form fluorescence for compound 5. In $\mathrm{CHCl}_{3}$ where the tautomeric equilibrium is shifted to hydrazoforms we have not observed radiative excited states with the lifetime $\tau_{2}$. Based on these findings we assigned the lifetime $\tau_{2}$ to the tautomeric forms $\mathbf{A}$ or $\mathbf{D}$. The main radiative deactivation pathways of compounds $\mathbf{3}$ to $\mathbf{5}$ (Table 3 ) is the process with the longest lifetime $\tau_{3}$. These are compounds which are substituted on the isatin moiety. This substitution leads to more consistent isatin nitrogen free electron pair involvement into the conjugation with the isatin $\pi$-electron system [23]. The isatin aromatic system charge density increasing decreases 
the tautomeric process probability. It supports hydrazone form these compounds existence. Based on the solvent and the concentration effect on tautomeric equilibrium the lifetime $\tau_{3}$ was assigned to the hydrazone aggregated forms and $\tau_{1}$ monomeric form [24]. Similar slightly lower lifetime values for other 1,8-naphthalimide hydrazones were measured in works [22,25].

\subsection{The Ions Effect on UV-Vis and Fluorescence Spectra of Isatin 1,8-Naphthalimide Hydrazones-Anion Sensors}

Studied hydrazones in the presence of fluoride, chloride and acetate ions in DMF provide coloured solutions similar to those in works $[2,3]$. These ions presence in the solution increases the dielectric medium properties and at the same time these ions interact with NH hydrazone hydrogen. Due to these processes the charge transfer occurs in the hydrazones that appears in new absorption band formation with the maximum around $630 \mathrm{~nm}$ in UV-Vis spectra (Scheme 3) which is practically identical with the tautomeric forms $\mathbf{A}$ and $\mathbf{D}$ bands (Scheme 2 and Figure 13). By the given hydrazone concentration the band intensity at $630 \mathrm{~nm}$ depends on the ions concentration in solution (Figure 14, Figure S4).

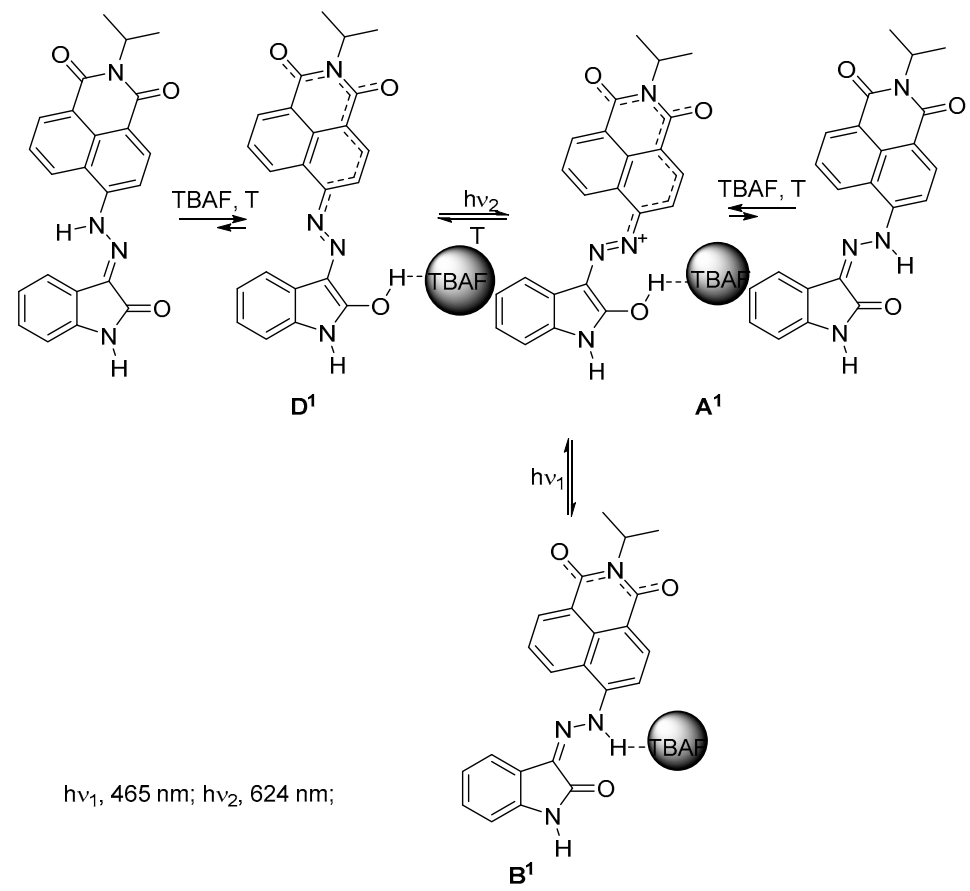

Scheme 3. TBAF effect on equilibrium and photochemical reactivity of studied compounds.
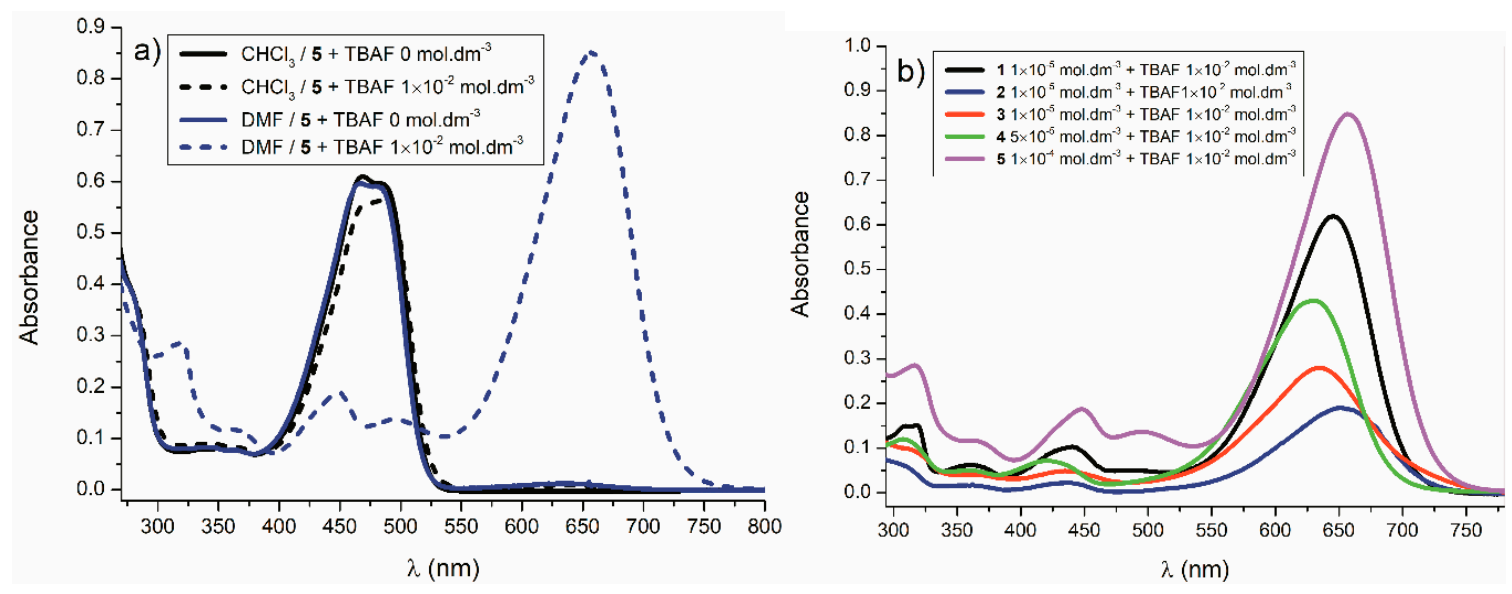

Figure 13. Hydrazone UV-Vis spectrum: (a) the solvent effect (DMF, $\mathrm{CHCl}_{3}$ ) and fluoride ions (tetrabutylammonium fluoride (TBAF)) effect on the UV-Vis spectrum of $5\left(1 \times 10^{-4} \mathrm{~mol} \cdot \mathrm{dm}^{-3}\right)$; (b) the hydrazone structure and TBAF effect on the UV-Vis spectrum of compounds 1-5 in DMF. 


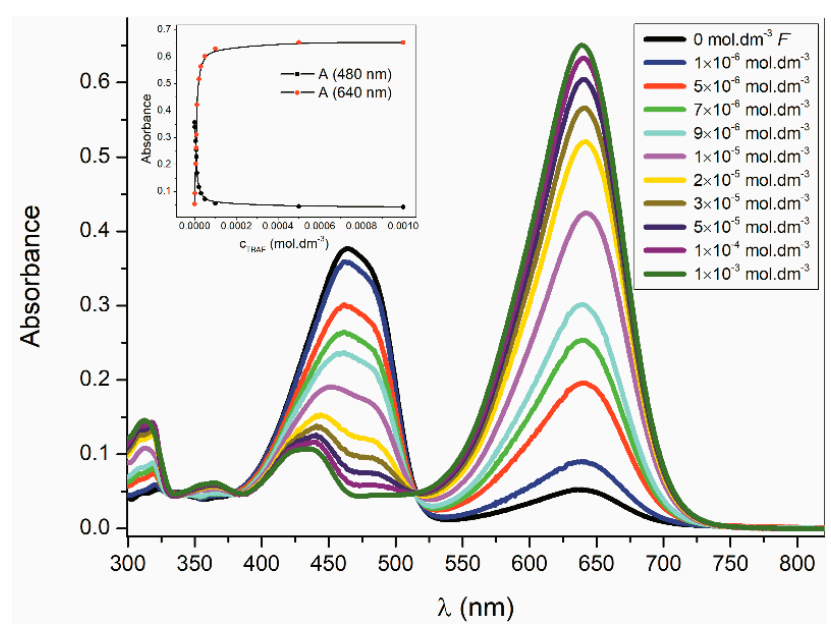

Figure 14. TBAF effect on UV-Vis spectra of compound $1\left(1 \times 10^{-5} \mathrm{~mol} \cdot \mathrm{dm}^{-3}\right)$ in DMF.

After ions addition to the hydrazone Z-isomer solution an intramolecular hydrogen bond is weakened by an anionic interaction and the tautomeric form $\mathbf{A}^{\mathbf{1}}$ is formed.

Within a few minutes after the ion addition to the solution on UV-Vis spectra the hypsochromic shift (approximately $15 \mathrm{~nm}$ ) of the originally formed band at $630 \mathrm{~nm}$ is observed (Figure 15).

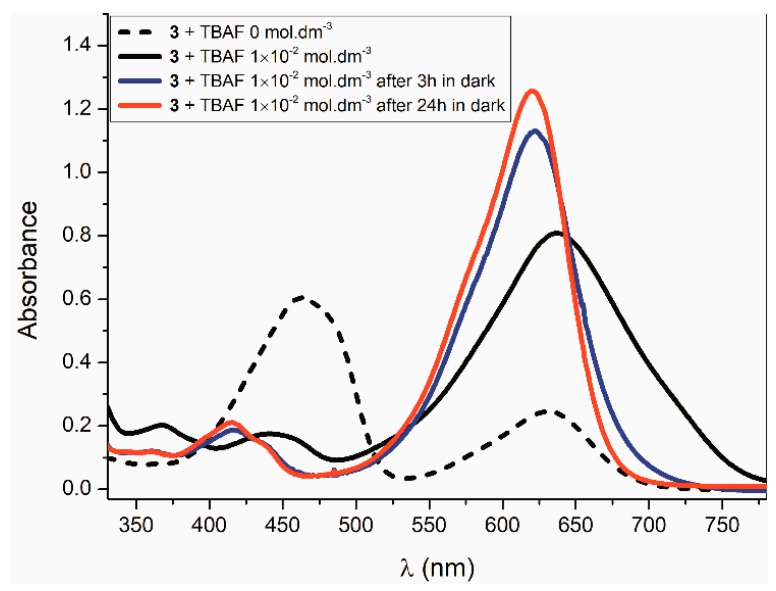

Figure 15. Compound $3\left(1 \times 10^{-5} \mathrm{~mol} \cdot \mathrm{dm}^{-3}\right) \mathrm{UV}$-Vis spectrum thermal change in the presence of TBAF $\left(1 \times 10^{-2} \mathrm{~mol} \cdot \mathrm{dm}^{-3}\right)$ in DMF.

During NMR experiment in $\mathrm{CDCl}_{3}$ and DMSO (supplementary Figures S5 and S6), after TBAF addition tautomeric change from $\mathbf{A}^{\mathbf{1}}$ to $\mathbf{D}^{\mathbf{1}}$ was observed according to proposed mechanism in Scheme 3 . This change is observed as a time dependent signal intensity change and is illustrated in Figures $\mathrm{S} 5$ and S6 as a black arrow for representing signals. Signal intensity decrease belongs to $\mathbf{A}^{1}$ and signal intensity increase to $\mathbf{D}^{\mathbf{1}}$ form respectively. These results are in good agreement with those ones observed by UV-Vis spectroscopy (Figure 15). $\mathrm{Cl}^{-}$ions (tetrabutylammonium chloride, TBACl) have significantly smaller effect on the studied hydrazones UV-Vis spectrum than $\mathrm{F}^{-}$or $\mathrm{CH}_{3} \mathrm{COO}^{-}$ions.

Depending on the hydrazone structure this effect is lesser than 200-1000 times (Figure 16). This is due to the lower $\mathrm{Cl}^{-}$ions basicity [26]. The size of $\mathrm{Cl}^{-}$ions impact on the UV-Vis spectrum (band intensity at $630 \mathrm{~nm}$ ) depends on the hydrazone structure or the hydrazone NH hydrogen acidity, therefore it maintains the same order as we observed for $\mathrm{F}^{-}$ions. $\mathrm{Cl}^{-}$ions have the largest effect on compound $\mathbf{3}$ (Figure 16). Similar to $\mathrm{F}^{-}$ions the thermal reaction between structures $\mathbf{A}^{\mathbf{1}}$ and $\mathbf{D}^{\mathbf{1}}$ (Scheme 3) was observed in the presence of $\mathrm{Cl}^{-}$ions too, which causes the band hypsochromic shift at $630 \mathrm{~nm}$ around approximately $5 \mathrm{~nm}$. 

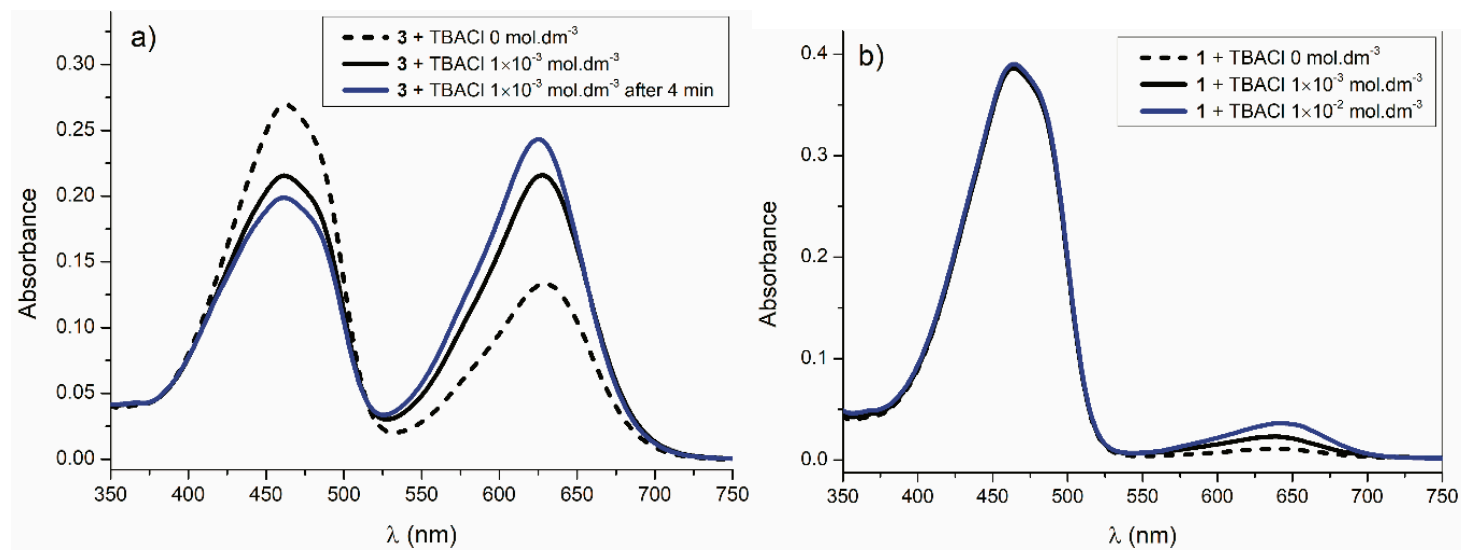

Figure 16. Effect of $\mathrm{Cl}^{-}$ions (TBACl) on UV-VIS spectra (a) compound $3\left(1 \times 10^{-5} \mathrm{~mol} \cdot \mathrm{dm}^{-3}\right)$; (b) compound $1\left(1 \times 10^{-5} \mathrm{~mol} \cdot \mathrm{dm}^{-3}\right)$ in DMF.

The influence of tetrabutylammonium bromide (TBABr) on the tautomeric equilibrium can be explained by different relative anion basicity (Figure 17). TBABr shifts the tautomeric equilibrium towards hydrazone form $\mathbf{B}$ (scheme 2). TBABr at the hydrazone concentrations at which the band can be observed at $630 \mathrm{~nm}$ in the UV-Vis spectra decrease this band intensity. A similar effect has TBABr also on the UV-Vis spectrum of compound 3 solution $\left(1 \times 10^{-5} \mathrm{~mol} \cdot \mathrm{dm}^{-3}\right)$ with TBAF $\left(1 \times 10^{-5} \mathrm{~mol} \cdot \mathrm{dm}^{-3}\right)$ (Figure 18).

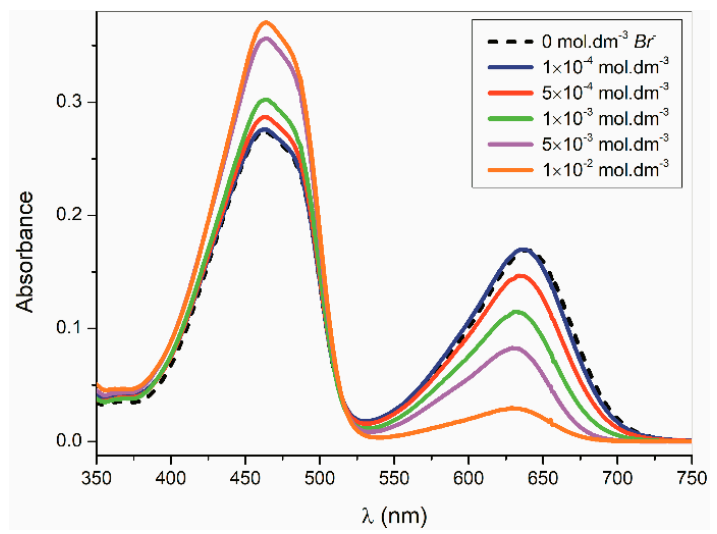

Figure 17. $\mathrm{Br}^{-}$ions (TBABr) effect on UV-VIS spectrum of compound $\mathbf{1}\left(1 \times 10^{-5} \mathrm{~mol} \cdot \mathrm{dm}^{-3}\right)$ in DMF.

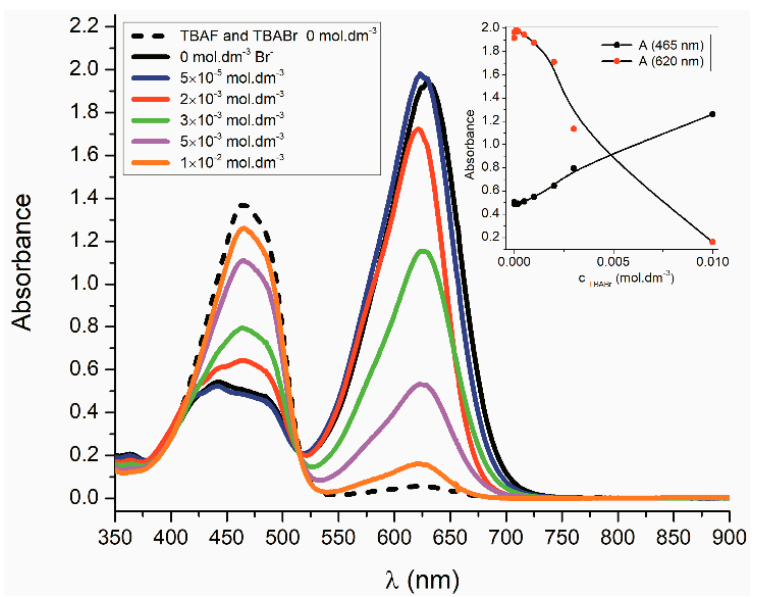

Figure 18. TBABr concentration effect on compound $3 \mathrm{UV}$-Vis spectra $\left(5 \times 10^{-5} \mathrm{~mol} \cdot \mathrm{dm}^{-3}\right)$ in the presence of TBAF $\left(5 \times 10^{-5} \mathrm{~mol} \cdot \mathrm{dm}^{-3}\right)$ in DMSO. 
The band intensity decreases about $72 \%$ at $630 \mathrm{~nm}$ (tautomer $\mathbf{A}^{\mathbf{1}}$ ) at the TBABr concentration $\left(5 \times 10^{-3} \mathrm{~mol} \cdot \mathrm{dm}^{-3}\right)$ equal to 100 times the TBAF concentration. Further decrease in absorbance is achieved (about $20 \%$ at $630 \mathrm{~nm}$ ) by increasing the TBABr concentration to $1 \times 10^{-2} \mathrm{~mol}^{\circ} \mathrm{dm}^{-3}(200$-fold excess). TBABr decreases the $\mathrm{F}^{-}$ability ions to interact with hydrazone $\mathrm{NH}$ hydrogen. We assume that $\mathrm{TBABr}$ electrostatically decreases the $\mathrm{F}^{-}$ions basicity in the way that these ions are no longer able to compete with intramolecular hydrogen bond in the studied Z-isomers. We estimated the studied hydrazones $\mathrm{pKa}$ value based on experiments with ions $\mathrm{PF}_{6}^{-}, \mathrm{HSO}_{4}^{-}, \mathrm{Br}^{-}, \mathrm{Cl}^{-}, \mathrm{NO}_{3}^{-}, \mathrm{F}^{-}$ and $\mathrm{CH}_{3} \mathrm{COO}^{-}$and $\mathrm{H}$-Bond Acceptor Parameters for Anions ( $\beta$ ) [26]. The pKa value is within the range: $0.9<\mathrm{pKa}<1.8$ i.e., between values of $\mathrm{pKa} \mathrm{Br}^{-}$and $\mathrm{Cl}^{-}$ions in DMSO. All studied hydrazones are selective sensors for fluoride and acetate anions.

From the data in Table 4 (detection and quantification limits) is evident that compounds 3 and 4 are-compared to the published data [27]—-so far very good $\mathrm{F}^{-}$ion sensors. Relatively high sensitivity of studied hydrazones also to the acetate ions presence (Table 4) decreases their selectivity or versatility as sensors to $\mathrm{F}^{-}$ions. Detection limit values (Table 4) suggest that the apparent association constants $\mathrm{K}_{\text {ass }}$ studied 1,8-naphthalimide derivatives will acquire high values in the presence of strongly basic $\mathrm{F}^{-}$ and $\mathrm{CH}_{3} \mathrm{COO}^{-}$anions in DMF. This was confirmed by the titration data non-linear fitting (absorption dependence on $\mathrm{F}^{-}$and $\mathrm{CH}_{3} \mathrm{COO}^{-}$ions concentration at $630 \mathrm{~nm}, 1: 1$ complex sensor anion). Thus, the obtained $\mathrm{K}_{\text {ass }}$ constants acquire very high, unrealistic values (for example supplementary Figure S7). Binding constants $\mathrm{K}_{\mathrm{ass}}$ accurate determination was prevented by the titration plot steep curvature. The unrealistic $\mathrm{K}_{\mathrm{ass}}$ constants might be caused by the titration process complexity. The titration process consists of several processes whose application degree depends on the ion concentration for the titration used. The ions presence also reflects in the studied compound fluorescence spectra. Tautomeric equilibrium effects the fluorescence (Scheme 3).

Table 4. Detection $(3 \sigma / \mathrm{S})$ and quantification $(10 \sigma / \mathrm{S})$ limits $\left(\mathrm{v}\right.$ mol.dm $\left.{ }^{-3}\right)$ of Z-izomers isatin 1,8-naphtalimide derivatives for strong basic $\mathrm{F}^{-}$a $\mathrm{CH}_{3} \mathrm{COO}^{-}$anions in $\mathrm{DMF}$ at 298,16 $\mathrm{K}$ (based on absorbance at $630 \mathrm{~nm} ; \sigma=0,005)$.

\begin{tabular}{|c|c|c|c|c|}
\hline Compound & $\begin{array}{c}3 \sigma / \mathrm{S} \mathrm{F}^{-} \\
\left(\mathrm{mol} \cdot \mathrm{dm}^{-3}\right)\end{array}$ & $\begin{array}{c}10 \sigma / \mathrm{S} \mathrm{F}^{-} \\
\left(\mathrm{mol} \cdot \mathrm{dm}^{-3}\right)\end{array}$ & $\begin{array}{c}3 \sigma / \mathrm{S} \mathrm{CH}_{3} \mathrm{COO}^{-} \\
\quad\left(\mathrm{mol} \cdot \mathrm{dm}^{-3}\right)\end{array}$ & $\begin{array}{c}10 \sigma / \mathrm{S} \mathrm{CH}_{3} \mathrm{COO}^{-} \\
\left(\mathrm{mol} \cdot \mathrm{dm}^{-3}\right)\end{array}$ \\
\hline 1 & $4.7 \times 10^{-7}$ & $1.6 \times 10^{-6}$ & $1.8 \times 10^{-6}$ & $6.0 \times 10^{-6}$ \\
\hline 2 & $1.7 \times 10^{-6}$ & $5.7 \times 10^{-6}$ & $1.3 \times 10^{-6}$ & $4.4 \times 10^{-6}$ \\
\hline 3 & $3.3 \times 10^{-8}$ & $1.1 \times 10^{-7}$ & $2.0 \times 10^{-7}$ & $6.6 \times 10^{-7}$ \\
\hline 4 & $8.3 \times 10^{-8}$ & $2.8 \times 10^{-7}$ & $8.5 \times 10^{-8}$ & $2.8 \times 10^{-7}$ \\
\hline 5 & $8.3 \times 10^{-7}$ & $2.8 \times 10^{-6}$ & $2.9 \times 10^{-6}$ & $9.7 \times 10^{-6}$ \\
\hline
\end{tabular}

$\sigma$-the standard deviation, $\mathrm{S}$ is the slope of the $A_{630}=f\left(c_{\mathrm{A}-}\right)$ in the initial linear portion of the curve, where $A_{630}$ is the absorbance value at $630 \mathrm{~nm}$ and $c_{\mathrm{A}}$ is the concentration of the corresponding anion; in all cases $n=10$.

After excitation at $465 \mathrm{~nm}$, the hydrazone form B or C fluorescence intensity decreases (Scheme 2) with maximum at $550 \mathrm{~nm}$, in the $\mathrm{F}^{-}$ions presence which shift the tautomeric equilibrium towards forms $\mathbf{A}^{\mathbf{1}}$ or $\mathbf{D}^{\mathbf{1}}$ (Figure 19). In the $\mathrm{F}^{-}$ions presence equilibrium shift towards the tautomeric form $\mathbf{A}^{\mathbf{1}}$ or $\mathbf{D}^{\mathbf{1}}$ after excitation $(630 \mathrm{~nm})$ is manifested by increase fluorescence intensity with maximum at $690 \mathrm{~nm}$ (Figure 19). 

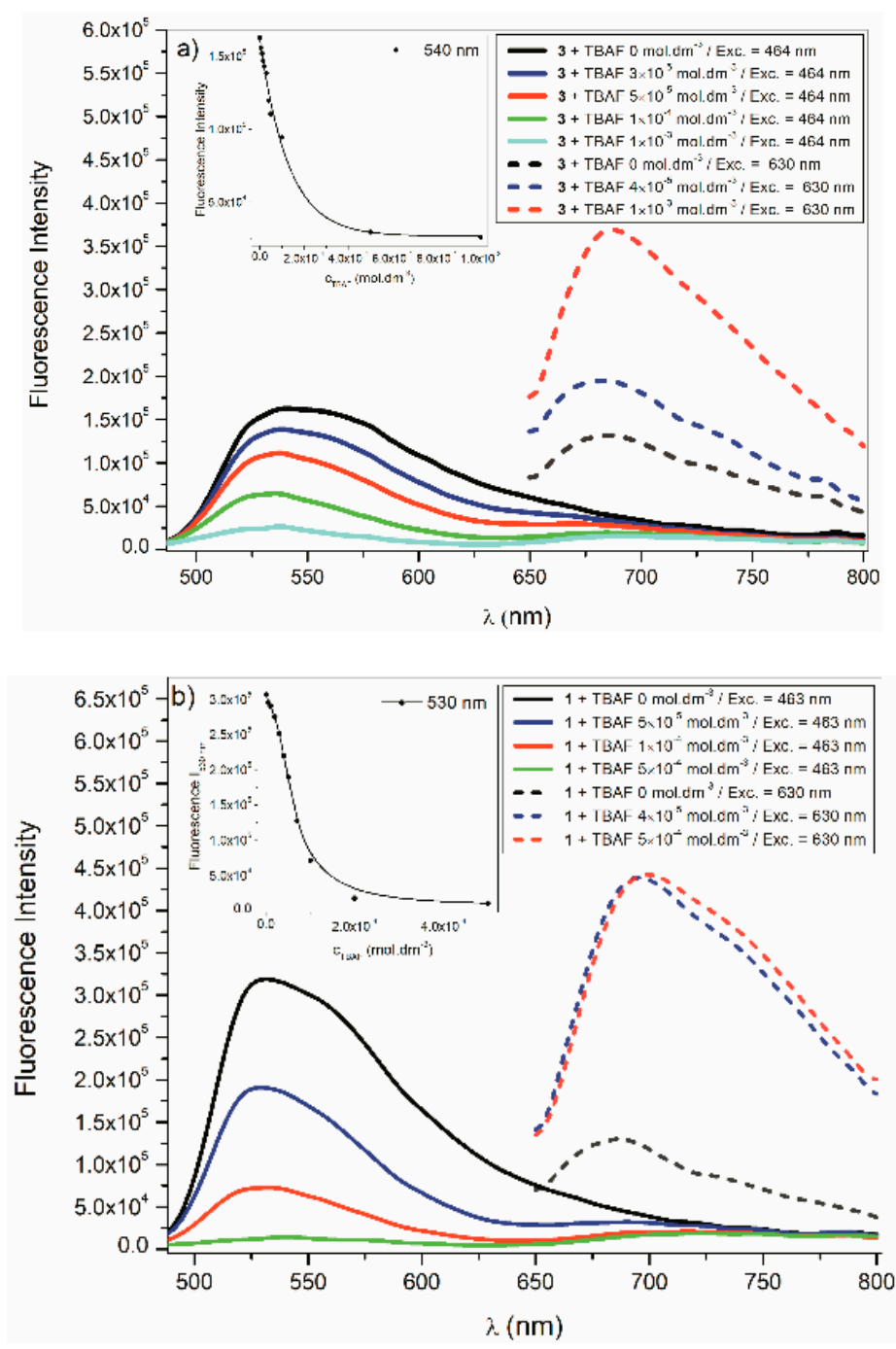

Figure 19. (a) compound $3\left(5 \times 10^{-5} \mathrm{~mol} \cdot \mathrm{dm}^{-3}\right)$ and (b) compound $\mathbf{1}\left(5 \times 10^{-5} \mathrm{~mol} \cdot \mathrm{dm}^{-3}\right)$ fluorescence spectra change in the presence of $F^{-}$ions in DMF $\left(\lambda_{\text {exc }}=465 \mathrm{~nm}\right.$ and $\left.630 \mathrm{~nm}\right)$.

\subsection{Light-Stimulated Isatin 1,8-Naphthalimide Hydrazones ON/OFF Properties or the System Isatin} 1,8-Naphthalimide Hydrazone + Anions

In the introduction to this discussion we have mentioned that the tautomeric change occurring between forms A and D (Scheme 2) in solvents such as DMF or DMSO is reversible. The reaction direction is controlled by light with different wavelength (Figure 8 ). This tautomeric equilibrium extent depends on the hydrazone structure [2,3], the environment dielectric properties and the hydrazine concentration or intermolecular interactions (association, etc.) that stabilize some of tautomeric forms. If light as the switching stimulus and as the response colorimetric or fluorescence change was used by the structure modification we can relatively easily adjust the switching spectral region, e.g., UV-Vis, Vis-Vis, and so on. For the given structure it is almost always necessary to "adjust" the conditions, these molecule surroundings to reach the ON/OFF switching reliable in sufficient range and fast enough. In this work the hydrazones structure has been designed so that the stimulus and colorimetric respond were in visible spectrum area i.e., Vis-Vis switching. Tautomeric equilibrium can be controlled by different energy means (465 $\mathrm{nm}$ and $624 \mathrm{~nm}$ ) (Figure 20). The reversibility, the stability of this process, the large differences in absorption maxima in the Vis spectra and the absorbance values give this hydrazone the potential for practical use as the signal switch. 


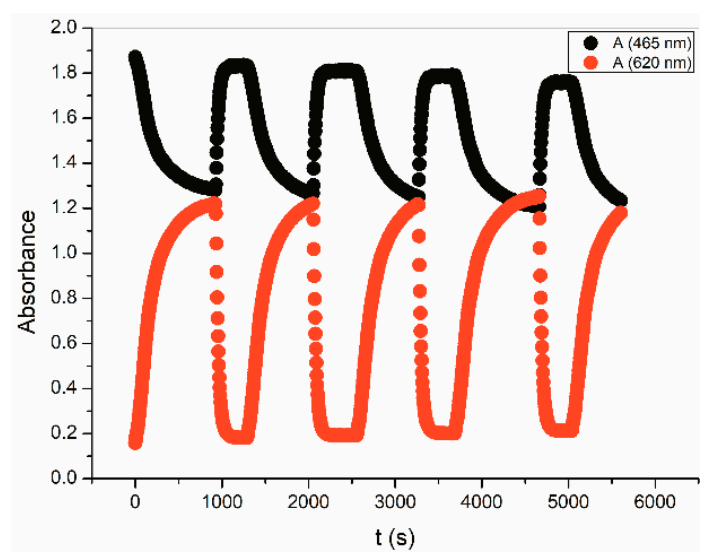

Figure 20. Absorption changes kinetic recording of absorption maxima during compound 3 irradiation alternately with light of different wavelength $(465 \mathrm{~nm}$ and $630 \mathrm{~nm})$ in DMF.

The compound 5 tautomeric equilibrium (Scheme 2) is almost completely shifted to the hydrazone side (Figure 1). Based on experimental measurements the hydrazones behaviour in the ions presence is described in Schemes 3 and 4. From the above described schemes is evident that interactions and combinations of thermal and photochemical reactions can affect or regulate the products $\mathbf{A}^{\mathbf{1}}$, $\mathbf{D}^{\mathbf{1}}$ and $\mathbf{B}^{\mathbf{1}}$ or $\mathbf{D}^{\mathbf{2}}$ and $\mathbf{A}^{\mathbf{2}}$ equilibrium abundance. The 1,8-naphthalimide fragment electron acceptor property increases the studied hydrazones hydrogen $\mathrm{NH}$ acidity to such an extent that in DMF at $\mathrm{F}^{-}$ concentration comparable to the equivalent concentration the tautomeric equilibrium is stabilized immediately after the $\mathrm{F}^{-}$ions addition in favour the form $\mathbf{A}^{\mathbf{1}}$ and /or $\mathbf{D}^{\mathbf{1}}, \mathbf{A}^{\mathbf{2}}$ and/or $\mathbf{D}^{\mathbf{2}}$ respectively. The UV-Vis spectrum is reversibly changed by this altered system irradiation with the wavelength $624 \mathrm{~nm}$ and $465 \mathrm{~nm}$ (Figure 21).

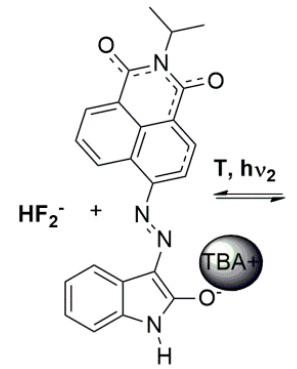

$D^{2}$

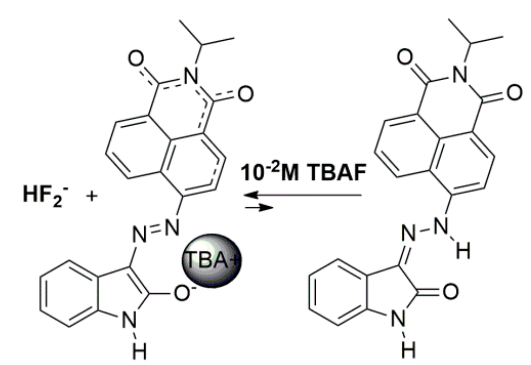

$A^{2}$

Scheme 4. NH hydrazone hydrogen cleavage at high TBAF excess and the formed product reactivity.

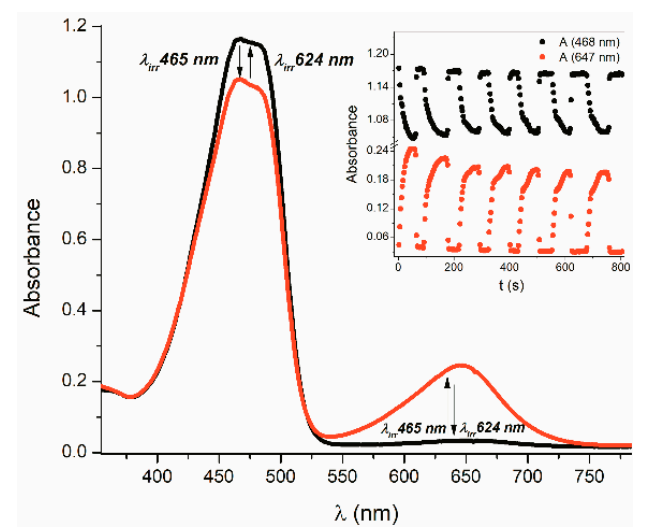

Figure 21. Compound $5\left(5 \times 10^{-5}\right.$ mol.dm $\left.{ }^{-3}\right)$ UV-Vis spectra change in the presence of TBAF $\left(2 \times 10^{-5} \mathrm{~mol} \cdot \mathrm{dm}^{-3}\right)$ during alternating irradiation with the wavelength light at $465 \mathrm{~nm}$ or $624 \mathrm{~nm}$ in DMF. 
The system has the molecular ON/OFF switch properties. Photochemical switching respectively the range of light-induced colorimetric changes depend on the $\mathrm{F}^{-}$ions concentration in the solution the solvent used and the hydrazone structure. In the given solvent there exist a relatively wide $\mathrm{F}^{-}$ ions concentration range ( 0.3 to 10 equivalents of TBAF) in which the logic 1 and 0 can be defined by colorimetric change with the certain and good resolution. This concentration range depends on the hydrazone structure as well as on the solvent properties. For all studied compounds with the $\mathrm{F}^{-}$ions high excess (about 100 equivalents) in DMF the UV-Vis spectrum of the hydrazone-TBAF system does not longer subject to the described reversible change. At a given light intensity that we have used as the stimulus it is not possible to carry out the photochemically induced tautomeric change. With such a high TBAF concentration excess hydrazone NH hydrogen is cleaved to form structure $\mathrm{A}^{2}$. The $\mathrm{HF}_{2}{ }^{-}$presence was proved by NMR spectroscopy. The structure thermal change $\mathbf{A}^{2}$ to $\mathbf{D}^{2}$ causes absorption band hypsochromic shift at $630 \mathrm{~nm}$ about $15 \mathrm{~nm}$ (Figure 15). Formed salt has no longer the ON/OFF switch properties. Using the light stimulus, it is not possible to change the achieved tautomeric equilibrium and to achieve the colorimetric response. By addition of water or other dielectrics (e.g., TBABr) it is possible to restore the functionality in this ON/OFF system. Interesting is the TBABr effect on the studied compounds ON/OFF functionality (Figure 22). The TBABr presence unlike TBAF shifts the tautomeric equilibrium towards the hydrazone form (Figure 17).
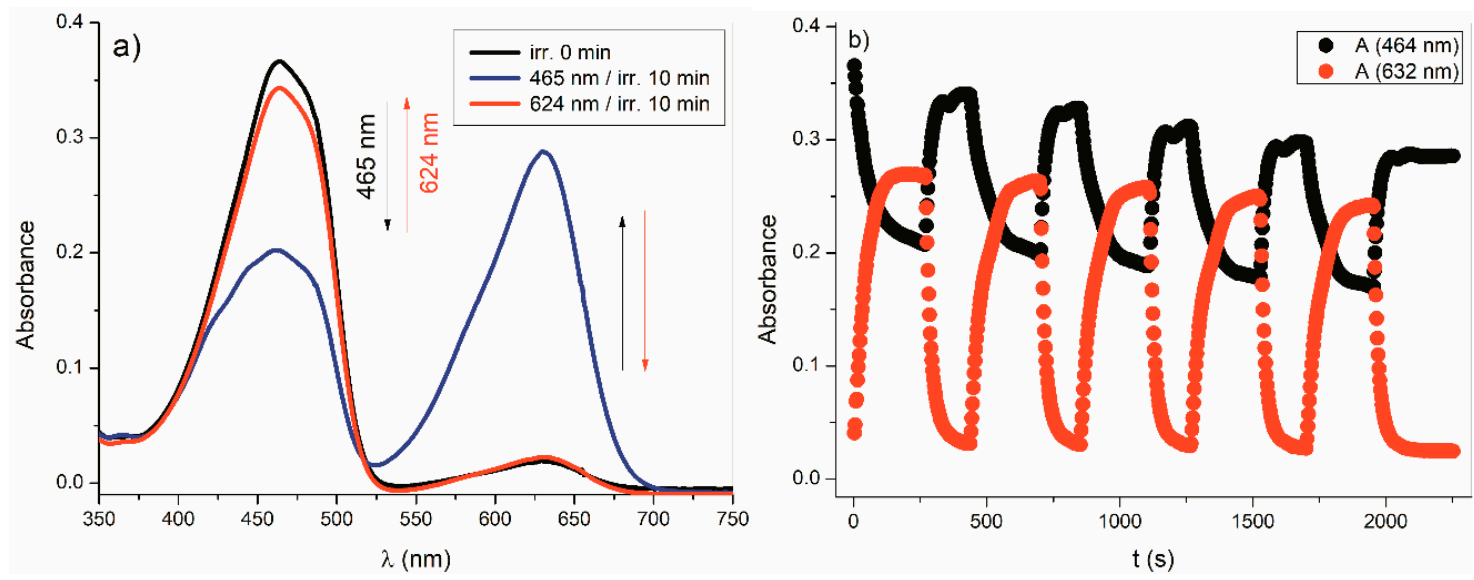

Figure 22. Compound $1\left(1 \times 10^{-5} \mathrm{~mol} \cdot \mathrm{dm}^{-3}\right)$ UV-VIS spectra change at the presence of TBABr $\left(1 \times 10^{-2} \mathrm{~mol} \cdot \mathrm{dm}^{-3}\right)($ a) during alternating light irradiation with the wavelength at $465 \mathrm{~nm}$ or $624 \mathrm{~nm}$ in DMF (b) kinetic recording.

If we alternately irradiate the system with the wavelength $465 \mathrm{~nm}$ and $624 \mathrm{~nm}$, it has the molecular $\mathrm{ON} / \mathrm{OFF}$ switch properties. But depending on the irradiation cycles number it is probable that the photochemical reaction takes place. This reflects in the response signal intensity gradual decrease (Figure 22). The HPLC and UV-Vis records (Figure 23) show that after hydrazones irradiation in $\mathrm{CHCl}_{3}$ and DMF with the wavelength $460 \mathrm{~nm}$ the $E$-isomer is formed in addition to $\mathbf{A}^{\mathbf{1}}$. Structures $\mathbf{A}^{\mathbf{1}}$ and $\mathbf{D}^{\mathbf{1}}$ cannot be monitored by HPLC. These are converted to $\mathbf{B}^{\mathbf{1}}$ during column separation. Subsequent reaction mixture irradiation $(624 \mathrm{~nm})$ the reaction products are converted to $\mathbf{B}^{\mathbf{1}}$. The system "hydrazone-TBAF" and "hydrazone-TBABr" ON/OFF switches differ. They have an inverse start at optimal ion concentration.

The switch with TBAF requires so as the switching "start" with the light with wavelength at $624 \mathrm{~nm}$. On the contrary the switch with TBABr must "start" with the light with wavelength at $465 \mathrm{~nm}$. In one case, the switch has a logic value of 1 in its initial state and in the second case a logical value of 0 . Similar or the same effect on ON/OFF switch functionality has also the TBABr addition to the TBAF hydrazone system (Figure 24). 

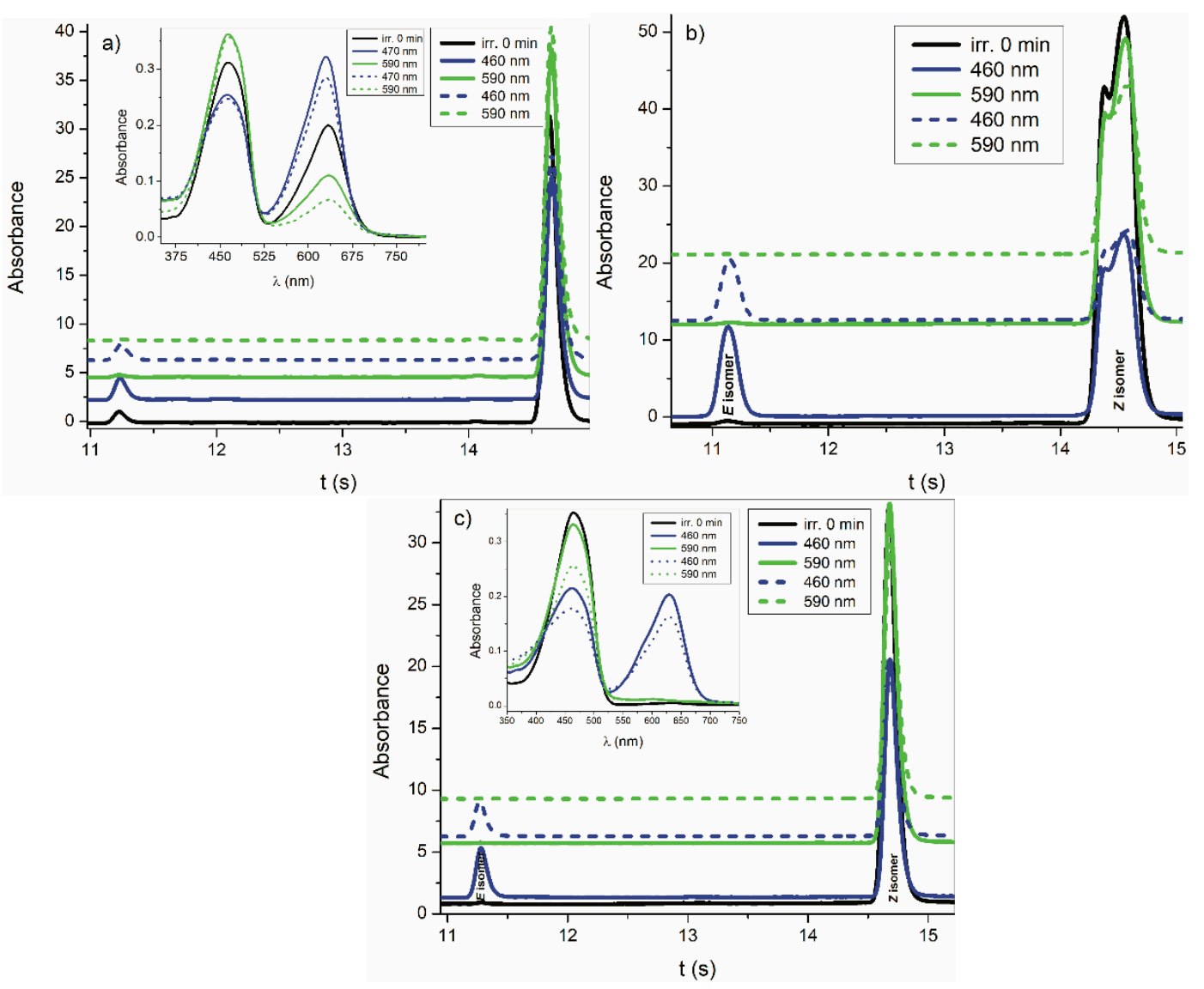

Figure 23. Reaction mixtures HPLC records after alternating light irradiation of compound 1 with the wavelength at $465 \mathrm{~nm}$ or $624 \mathrm{~nm}$; (a) $1 \times 10^{-5} \mathrm{~mol} \cdot \mathrm{dm}^{-3}$ compound $1+1 \times 10^{-5} \mathrm{~mol} \cdot \mathrm{dm}^{-3}$ TBAF in DMF; (b) $5 \times 10^{-5} \mathrm{~mol} \cdot \mathrm{dm}^{-3}$ compound $\mathbf{1}+2 \times 10^{-4} \mathrm{~mol} \cdot \mathrm{dm}^{-3} \mathrm{TBAF}$ in $\mathrm{CHCl}_{3}$; (c) $1 \times 10^{-5} \mathrm{~mol} \cdot \mathrm{dm}^{-3}$ compound $1+1 \times 10^{-2} \mathrm{~mol} \cdot \mathrm{dm}^{-3} \mathrm{TBABr}$ in DMF (in set: corresponding UV-Vis spectral changes).

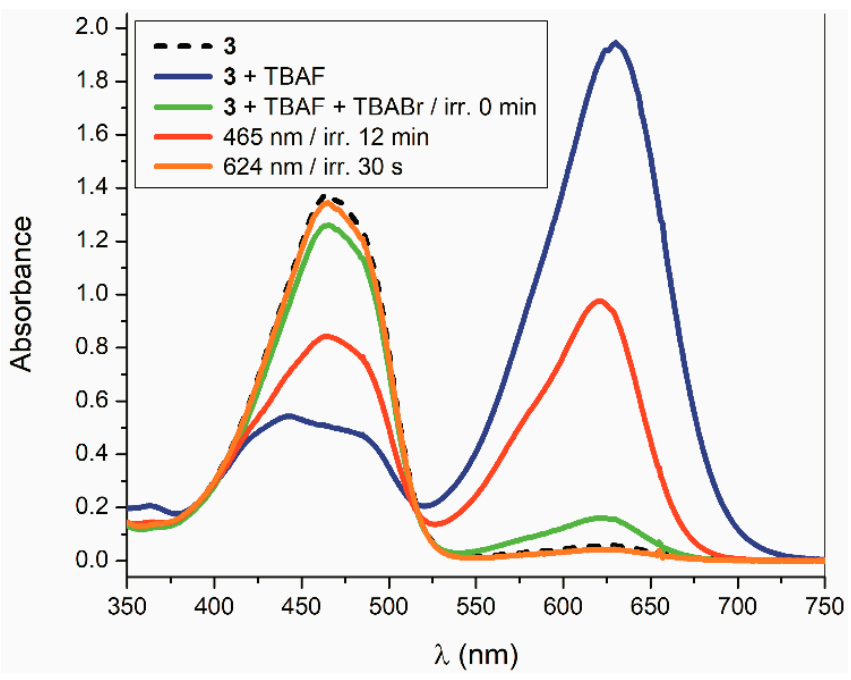

Figure 24. Compound $3\left(5 \times 10^{-5} \mathrm{~mol} \cdot \mathrm{dm}^{-3}\right)$ UV-VIS spectra change at the presence of TBAF $\left(5 \times 10^{-5} \mathrm{~mol} \cdot \mathrm{dm}^{-3}\right)$ and $\operatorname{TBABr}\left(1 \times 10^{-2} \mathrm{~mol} \cdot \mathrm{dm}^{-3}\right)$ after alternating light irradiation with the wavelength at $465 \mathrm{~nm}$ and $624 \mathrm{~nm}$, in DMSO. 
From all studied hydrazones only for compound 5 we did not observe the $\mathbf{A}^{2}$ to $\mathbf{D}^{2}$ thermal change (Scheme 4). We assume that the $\mathbf{D}^{2}$ formation hinders the spatial demands of the 1,8-naphthalimide and 4-dimethoxyphenyl attached to isatin fragment in the structure. Photochemically, this process also takes place at compound 5 , but structure $\mathbf{D}^{2}$ thermally returns to $\mathbf{A}^{2}$ again. Solvents depending on how they affect the tautomeric equilibrium can be divided into two groups. The first group consists of the solvents such as DMF, DMSO and $\mathrm{CH}_{3} \mathrm{CN}$, which affect tautomeric equilibrium in the same direction as $\mathrm{F}^{-}$ions. They increase the tautomeric reaction rate. The equilibrium state is reached immediately after dissolution of the compounds in these solvents. They stabilize tautomeric forms $\mathbf{A}$ and $\mathbf{D}$. The second group consist of solvents, e.g., $\mathrm{CHCl}_{3}$, which, on the contrary, decrease the tautomerisation rate. They shift the tautomeric equilibrium to the hydrazone form. In $\mathrm{CHCl}_{3}$ this tautomeric equilibrium rate is significantly slowed as compared to the rate in DMF, DMSO and $\mathrm{CH}_{3} \mathrm{CN}$. E.g. the rate of tautomerization of compound 1 in $\mathrm{CHCl}_{3}$ at $25^{\circ} \mathrm{C}$ is equal to $\mathrm{k}_{25}{ }^{\circ} \mathrm{C}=1.52 \times 10^{-3} \mathrm{~s}^{-1}$. Arrhenius activation energy for this compound is $\Delta \mathrm{E}_{\mathrm{Arh}}=53.2 \mathrm{~kJ} \cdot \mathrm{mol}^{-1}$ (Figure 25). In this case the thermal rate of the tautomeric forms $\mathbf{A}^{\mathbf{1}}$ and/or $\mathbf{D}^{\mathbf{1}}$ or $\mathbf{A}^{\mathbf{2}}$ and/or $\mathbf{D}^{\mathbf{2}}$ is slower than the photoreaction rates the product of which is the hydrazone form.

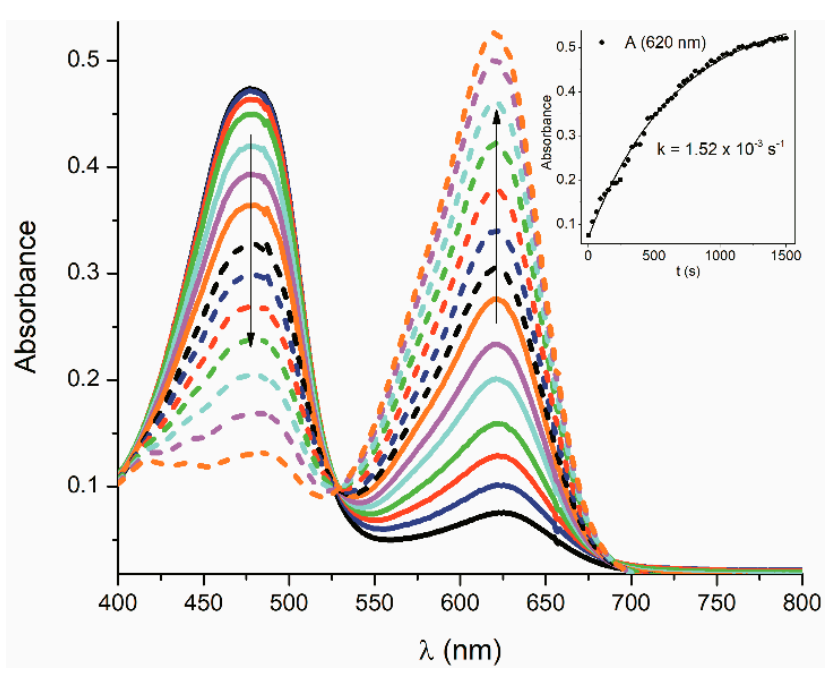

Figure 25. Compound $1\left(5 \times 10^{-5} \mathrm{~mol} \cdot \mathrm{dm}^{-3}\right)$ thermal kinetics $\left(25^{\circ} \mathrm{C}\right)$ in the presence of TBAF $\left(1 \times 10^{-2} \mathrm{~mol} \cdot \mathrm{dm}^{-3}\right)$ in $\mathrm{CHCl}_{3}$.

Therefore, we can "return" the tautomeric equilibrium to the hydrazone form by a light stimulus at given intensity (624 nm) (Figure 26). From Figure 26 is evident that the hydrazones are in $\mathrm{CHCl}_{3}$ not photochemically stable.

These results however show that the conditions selection make it is possible to affect the tautomeric reaction rate as well as the system stability and thus restore or revive its ON/OFF functionality. Of all previously studied isatin hydrazones only isatin 1,8-naphthalimide hydrazones allowed us to monitor the response to the stimulus by fluorescence. This is caused by both the fluorescence quantum yield but also by the fact that both tautomeric forms exhibit fluorescence and that the tautomeric forms $\mathbf{A}$ and $\mathbf{D}$ can be excitated selectively independently from the hydrazone forms (Figure 27). In Figure 27 fluorescence spectrum changes after excitation at $630 \mathrm{~nm}$ in the alternating irradiation of 3 with the wavelength at $465 \mathrm{~nm}$ and $624 \mathrm{~nm}$ can be seen. This ON/OFF functionality corresponds to the tautomeric form B, C to form $\mathbf{A}$ or $\mathbf{D}$ reversible change. At $465 \mathrm{~nm}$ excitation, the system behaves equally, while irradiating the sample with light at to the molecule geometry change but mainly it is caused $624 \mathrm{~nm}$, leads to the fluorescence band bathochromic shift at $550 \mathrm{~nm}$. This maximum shift is related by the hydrazone form concentration change in the solution or its association. After the sample irradiation the fluorescence intensity is always lower, than the fluorescence intensity using $465 \mathrm{~nm}$ light at $624 \mathrm{~nm}$. 


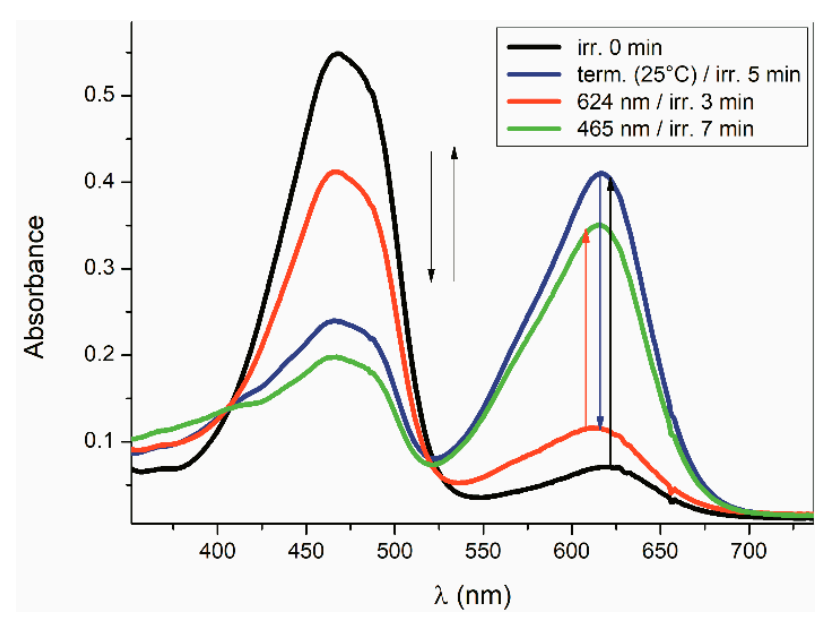

Figure 26. Compound $1\left(5 \times 10^{-5} \mathrm{~mol} \cdot \mathrm{dm}^{-3}\right)$ UV-VIS spectra change at the presence of TBAF $\left(2 \times 10^{-4} \mathrm{~mol} \cdot \mathrm{dm}^{-3}\right)$ after light irradiation with the wavelength at $465 \mathrm{~nm}$ and $624 \mathrm{~nm}$ in $\mathrm{CHCl}_{3}$.
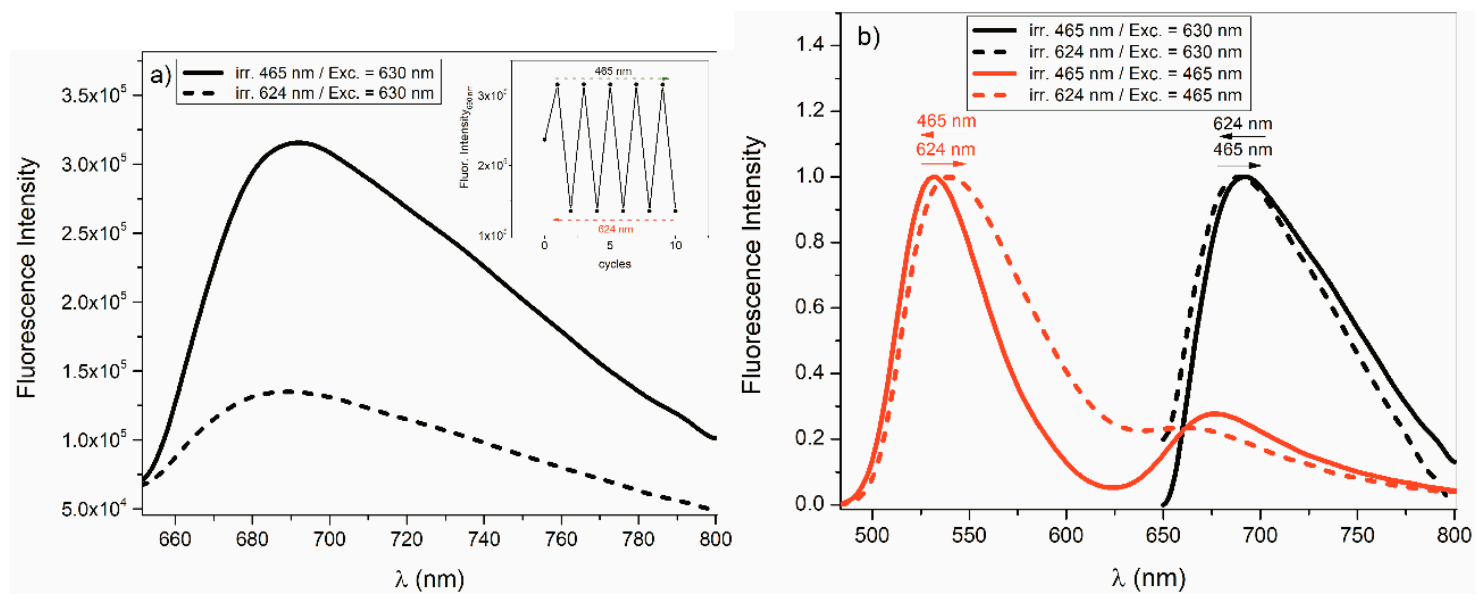

Figure 27. Fluorescence spectrum change $\left(\lambda_{\text {exc. }}=630 \mathrm{~nm}\right)$ alternately irradiated compound 3 $\left(1 \times 10^{-4} \mathrm{~mol} \cdot \mathrm{dm}^{-3}\right)$ with wavelength light at $465 \mathrm{~nm}$ a $624 \mathrm{~nm}$ in DMF (a) normalised fluorescence spectra $\left(\lambda_{\text {exc }}=465 \mathrm{~nm}\right.$ or $\left.630 \mathrm{~nm}\right)$ of compound 3 after $\lambda_{\text {exc. }}=465 \mathrm{~nm}$ or $630 \mathrm{~nm}$ in DMF (b).

\section{Materials and Methods}

\subsection{General Information}

All chemicals used for synthesis were purchased from Sigma-Aldrich (St. Louis, MO, USA). Solvents were dried and purified by standard methods prior to use. The samples were irradiated in the device's own construction directly in the spectrometer's cell by means of LEDs (electrical input 30 to $120 \mathrm{~mW}$ ). Flash chromatography was performed on Merck (Darmstadt, Germany) silica gel 60.

\subsection{Synthesis}

A mixture of derivatized isatin $(0.4 \mathrm{mmol})$ and hydrazino isoquinoline 1,3 -dione $(0.4 \mathrm{mmol})$ in $n$-butanol $(40 \mathrm{~mL})$ was heated to reflux for $24 \mathrm{~h}$. The reaction mixture was concentrated, and the residue was washed several times with hot ethanol to a clear solution. Red solids were isolated.

2-(2-Propyl)-6-[N'-(2-oxo-1,2-dihydroindol-3-ylidene)-hydrazino]-benzo[de] isoquinoline-1,3-dione (1, >99\%, $0.16 \mathrm{~g}):{ }^{1} \mathrm{H}-\mathrm{NMR}$ (300 MHz, DMSO): $\delta 14.03$ (s, 1H, = NNH), 11.38 (s, 1H, NH $\left.\mathrm{NH}_{\mathrm{s}}\right), 8.53(\mathrm{~m}, 2 \mathrm{H}), 8.29$ (d, $1 \mathrm{H}, J=8.1 \mathrm{~Hz}), 7.99(\mathrm{~m}, 2 \mathrm{H}), 7.68(\mathrm{~d}, 1 \mathrm{H}, J=7.4 \mathrm{~Hz}), 7.35(\mathrm{~d}, 1 \mathrm{H}, J=8.2 \mathrm{~Hz}), 7.14(\mathrm{~d}, 1 \mathrm{H}, J=7.4 \mathrm{~Hz})$, $6.99(\mathrm{~d}, 1 \mathrm{H}, \mathrm{J}=7.3 \mathrm{~Hz}), 5.40-5.22(\mathrm{~m}, 1 \mathrm{H}, \mathrm{CH}), 1.52\left(\mathrm{~d}, 6 \mathrm{H}, \mathrm{CH}_{3}, J=6.8 \mathrm{~Hz}\right) .{ }^{13} \mathrm{C}-\mathrm{NMR}$-due to its 
extremely low solubility, it was not possible to measure it. Elem. anal. calcd. for $\mathrm{C}_{23} \mathrm{H}_{18} \mathrm{~N}_{4} \mathrm{O}_{3}$ : C 69.34, H 4.55; N 14.06. found: C 59.96; H 4.14; N 23.16. IR (ATR) v/ $\mathrm{cm}^{-1}$ : 3170, 2961, 1687, 1567, 1357, 786, 733. m. p.: $287-289^{\circ} \mathrm{C}$.

2-Amino-6-[N'-(2-oxo-1,2-dihydro-indol-3-ylidene)-hydrazino]-benzo[de]isoquinoline-1,3-dione (2, 97\%, $0.14 \mathrm{~g})$ : ${ }^{1} \mathrm{H}-\mathrm{NMR}$ (300 MHz, DMSO): $\delta 14.07(\mathrm{~s}, 1 \mathrm{H},=\mathrm{NNH}), 11.38\left(\mathrm{~s}, 1 \mathrm{H}, \mathrm{NH}_{\mathrm{is}}\right), 8.54-8.60(\mathrm{~m}, 1 \mathrm{H}), 8.31-8.35$ $(\mathrm{m}, 1 \mathrm{H}), 8.06-7.97(\mathrm{~m}, 1 \mathrm{H}), 7.76-7.69(\mathrm{~m}, 1 \mathrm{H}), 7.35-7.43(\mathrm{~m}, 1 \mathrm{H}), 7.12-7.17(\mathrm{~m}, 1 \mathrm{H}), 6.98-7.02(\mathrm{~m}, 1 \mathrm{H})$, $5.79(\mathrm{~m}, 1 \mathrm{H}), 3.19\left(\mathrm{~s}, 2 \mathrm{H}, \mathrm{N}(\mathrm{CO})_{2} \mathrm{NH}_{2}\right) .{ }^{13} \mathrm{C}-\mathrm{NMR}$-due to its extremely low solubility, it was not possible to measure it. Elem. anal. calcd. for $\mathrm{C}_{20} \mathrm{H}_{13} \mathrm{~N}_{5} \mathrm{O}_{3}: \mathrm{C} 64.69 ; \mathrm{H} 3.53 ; \mathrm{N} 18.86$; found: $\mathrm{C} 64.68, \mathrm{H}$, 3.99; N, 18.88. IR (ATR) $v / \mathrm{cm}^{-1}: 3314,3110,1681,1648,1372,754,746$. m. p.: $>300{ }^{\circ} \mathrm{C}$.

2-(2-Propyl)-6-[N'-(2-oxo-5-trifluoromethoxy-1,2-dihydro-indol-3-ylidene)hydrazino]benzo[de]iso-quinoline-1,3dione (3, $99 \%, 0.19 \mathrm{~g}):{ }^{1} \mathrm{H}-\mathrm{NMR}(300 \mathrm{MHz}, \mathrm{DMSO}): \delta 13.99(\mathrm{~s}, 1 \mathrm{H},=\mathrm{NNH}), 11.54\left(\mathrm{~s}, 1 \mathrm{H}, \mathrm{NH}_{\mathrm{is}}\right), 8.55(\mathrm{~m}$, $2 \mathrm{H}), 8.31(\mathrm{~m}, 1 \mathrm{H}), 8.12(\mathrm{dd}, 1 \mathrm{H}, J=8.4,2.4 \mathrm{~Hz}), 7.99(\mathrm{dd}, 1 \mathrm{H}, J=15.5,7.3 \mathrm{~Hz}), 7.68(\mathrm{~m}, 1 \mathrm{H}), 7.36(\mathrm{~d}, 1 \mathrm{H}$, $J=8.7 \mathrm{~Hz}), 7.08(\mathrm{~d}, 1 \mathrm{H}, J=8.6 \mathrm{~Hz}), 5.31(\mathrm{~m}, 1 \mathrm{H}, \mathrm{CH}), 1.52\left(\mathrm{~d}, 6 \mathrm{H}, \mathrm{CH}_{3}, J=6.9 \mathrm{~Hz}\right) .{ }^{19} \mathrm{~F}-\mathrm{NMR}(282 \mathrm{MHz}$, DMSO): $\delta$-57.22 ppm. ${ }^{13} \mathrm{C}-\mathrm{NMR}$-due to its extremely low solubility, it was not possible to measure it. Elem. anal. calcd. for $\mathrm{C}_{24} \mathrm{H}_{17} \mathrm{~F}_{3} \mathrm{~N}_{4} \mathrm{O}_{4}$ : C 59.75, H 3.55, N 11.61. found: C 60.02, H 3.49, N 11.60.IR (ATR) $v / \mathrm{cm}^{-1}: 3221,1621,1558,1132$, 777. m.p.: $276-277^{\circ} \mathrm{C}$.

2-(2-Propyl)-6-[N'-(1-methyl-2-oxo-5-trifluoromethoxy-1,2-dihydro-indol-3-ylidene)hydrazino]-benzo[de] isoquinoline-1,3-dione (4, 99\%, $0.19 \mathrm{~g}):{ }^{1} \mathrm{H}-\mathrm{NMR}(300 \mathrm{MHz}, \mathrm{DMSO}): \delta 13.95(\mathrm{~s}, 1 \mathrm{H},=\mathrm{NNH}), 8.57-8.50(\mathrm{~m}$, $1 \mathrm{H}), 8.39-8.32(\mathrm{~m}, 2 \mathrm{H}), 8.17-8.13(\mathrm{~m}, 1 \mathrm{H}), 7.99-8.02(\mathrm{~m}, 1 \mathrm{H}), 7.74(\mathrm{~m}, 1 \mathrm{H}), 7.46-7.49(\mathrm{~m}, 1 \mathrm{H}), 7.34-7.31$ $(\mathrm{m}, 1 \mathrm{H}), 5.80(\mathrm{~s}, 1 \mathrm{H}, \mathrm{CH}), 3.35\left(\mathrm{~s}, 3 \mathrm{H}, \mathrm{CH}_{3}\right.$ is $), 1.53-1.51\left(\mathrm{~d}, 6 \mathrm{H}, \mathrm{CH}_{3}\right) \mathrm{ppm} .{ }^{13} \mathrm{C}-\mathrm{NMR}$-due to its extremely low solubility, it was not possible to measure it. ${ }^{19} \mathrm{~F}-\mathrm{NMR}$ (282 MHz, DMSO): $\delta$ - $57.22 \mathrm{ppm}$. Elem. anal. calcd. for $\mathrm{C}_{25} \mathrm{H}_{19} \mathrm{~F}_{3} \mathrm{~N}_{4} \mathrm{O}_{4}$ : C. 60.48, H 3.86, N, 11.29. found: $\mathrm{C} 60.50, \mathrm{H} \mathrm{3.99,} \mathrm{N} \mathrm{11.28.} \mathrm{IR}$ (ATR) $v / \mathrm{cm}^{-1}: 3023,2931,1650,1566,1099,775$. m.p.: $254-256^{\circ} \mathrm{C}$.

6-\{N'-[4-(2,6-Dimethoxyphenyl)-2-oxo-1,2-dihydro-indol-3-ylidene]hydrazino\}-2-(2-propyl)-benzo[de] isoquinoline-1,3-dione (5, 71\%, $0.15 \mathrm{~g})$ : $E$ isomer $-{ }^{1} \mathrm{H}-\mathrm{NMR}(300 \mathrm{MHz}, \mathrm{DMSO}): \delta 13.88(\mathrm{~s}, 1 \mathrm{H}, \mathrm{NH})$, $11.34(\mathrm{~s}, 1 \mathrm{H}, \mathrm{NH}), 8.48(\mathrm{~d}, 1 \mathrm{H}, J=7.3 \mathrm{~Hz}), 8.24(\mathrm{~d}, 1 \mathrm{H}, J=8.3 \mathrm{~Hz}), 8.15(\mathrm{~d}, 1 \mathrm{H}, J=8.3 \mathrm{~Hz}), 7.88(\mathrm{dd}, 1 \mathrm{H}$, $J=8.3 ; 7.4 \mathrm{~Hz}), 7.53(\mathrm{t}, 1 \mathrm{H}, J=8.4 \mathrm{~Hz}), 7.32(\mathrm{t}, 1 \mathrm{H}, J=7.7 \mathrm{~Hz}), 7.00(\mathrm{~d}, 1 \mathrm{H}, J=8.4 \mathrm{~Hz}), 6.90(\mathrm{~m}, 4 \mathrm{H})$, $5.27(\mathrm{~m}, 1 \mathrm{H}, \mathrm{CH}), 3.60\left(\mathrm{~s}, 6 \mathrm{H}, \mathrm{OCH}_{3}\right), 1.48(\mathrm{~d}, 6 \mathrm{H}) \mathrm{ppm} .{ }^{13} \mathrm{C}-\mathrm{NMR}$ (75 MHz, DMSO): $\delta 164.12,164.11$, 163.63, 157.64, 143.49, 141.58, 133.74, 132.50, 131.42, 130.11, 129.86, 129.10, 127.21, 126.24, 126.15, 123.47, $119.32,119.00,116.22,115.52,109.97,108.26,104.78,56.04,44.50,25.79,19.99$, ppm. Elem. anal. calcd. for $\mathrm{C}_{31} \mathrm{H}_{26} \mathrm{~N}_{4} \mathrm{O}_{5}$ : C 69.65, H 4.90, N 10.48. found: C 70.62, H 4.98; N 10.47. IR (ATR) v/cm ${ }^{-1}$ : 3299, 2945, 1689, 1566, 771, 753. m.p.: 293-295 ${ }^{\circ} \mathrm{C}$.

\subsection{Spectroscopic Measurements}

NMR spectra were recorded in $5 \mathrm{~mm}$ NMR tubes on a Varian NMR System $300\left(300 \mathrm{MHz}\right.$ for ${ }^{1} \mathrm{H}$, $75 \mathrm{MHz}$ for ${ }^{13} \mathrm{C}$ and $282 \mathrm{MHz}$ for $\left.{ }^{19} \mathrm{~F}\right)$ or VNMRS $600 \mathrm{MHz}$ spectrometer $\left(600 \mathrm{MHz}\right.$ for ${ }^{1} \mathrm{H} ; 150 \mathrm{MHz}$ for ${ }^{13} \mathrm{C}$, Varian, Inc., Palo Alto, CA, USA) in DMSO- $d_{6}$ and $\mathrm{CDCl}_{3}$ as solvents ( $\mathrm{c}_{\text {sensor }}=1 \times 10^{-4}$; anion concentration up to 30 equivalents). Chemical shifts are referenced to tetramethylsilane (TMS) as an internal standard. Attenuated total reflection Fourier transform infrared (ATR-FTIR) spectra of all the described experiments were measured on a Nicolet 6700 FTIR (from ThermoNicolet Corp., Madison, WI, USA). Spectra were recorded with ATR mathematical corrections yielding a $1.0 \mathrm{~cm}^{-1}$ actual resolution and 40 measurements were averaged. Spectra for liquid samples were measured in a cell with $\mathrm{CaF}_{2}$ windows and a path length of $0.2 \mathrm{~mm}$. Electronic absorption spectra were obtained on a HP 8452A diode array spectrophotometer (Hewlett Packard, Palo Alto, CA, USA). Solution fluorescence was measured in a $1 \mathrm{~cm}$ cuvette with an FSP 920 (Edinburgh Instruments, Edinburgh, $\mathrm{UK}$ ) spectrofluorimeter in a right-angle or front-face arrangement (to exclude solution self-absorption). The solvents used $\left(\mathrm{CHCl}_{3}\right.$, DMSO, DMF) were HPLC $\left(\mathrm{CHCl}_{3}\right.$; LiChrosolv ${ }^{\circledR}$, Merck, Darmstadt, Germany) or UV-spectroscopy grade (DMSO and DMF; Uvasol ${ }^{\circledR}$, Merck) and were used without 
further purification. Detailed determination of association constant for apparent 1:1 complex is described in ESI Association constant determinations.

\subsection{HPLC Chromatography}

HPLC chromatography was carried out using a chromatographic system (Agilent Technologies, Santa Clara, CA, USA) consisting of a quaternary pump, thermostated column compartment, a diode array detector (VWDG 1314A), manual injector (Rheodyne model 7725i) with $20 \mu \mathrm{L}$ sample loop, and a degasser (g1379A) all the 1100 series. For all experiments, Column ZORBAXSB- Phenyl (150 $\mathrm{mm} \times 4.6 \mathrm{~mm}$ i.d.) was used. For analyses of $\mathrm{I}$, mobile phase A was a methanol/water mixture $(\varphi r=1: 99)$ and phase B was acetonitrile. In the analysis of isomers, the isocratic gradient $A / B(\varphi r=1: 1)$ at the flow rate of $0.6 \mathrm{~mL} \mathrm{~min} \mathrm{~m}^{-1}$ at $22{ }^{\circ} \mathrm{C}$ and detection at $236 \mathrm{~nm}$ was used. The injection volume was $20 \mu \mathrm{L}$. For analyses of II, mobile phase A was a methanol/water mixture $(\varphi \mathrm{r}=1: 99)$ and phase B was methanol. In the analysis of isomers, the isocratic gradient $\mathrm{A} / \mathrm{B}(\varphi \mathrm{r}=37: 13)$ at the flow rate of $0.6 \mathrm{~mL}$ $\min ^{-1}$ at $22{ }^{\circ} \mathrm{C}$ and detection at $236 \mathrm{~nm}$ was used. The injection volume was $20 \mu \mathrm{L}$.

\section{Conclusions}

Five new isatin 1,8-naphthalimide hydrazones were prepared. These compounds' UV-VIS and fluorescence spectra are dependent on their concentration in aprotic solvents with a high dielectric constant. By decreasing the hydrazone concentration $\left(c=1 \times 10^{-4} \mathrm{~mol}_{\mathrm{dm}}{ }^{-3}\right)$ a new absorption band is formed in the UV-VIS spectra, which maximum depends on the hydrazone structure and is in the $625-650 \mathrm{~nm}$ range. The band absorbance increase is accompanied by the band absorbance decrease at $460 \mathrm{~nm}$ with isosbestic points maintenance at 518 and $373 \mathrm{~nm}$. At the hydrazone concentration higher than $4 \times 10^{-5} \mathrm{~mol} \cdot \mathrm{dm}^{-3}$ the fluorescence band at $550 \mathrm{~nm}$ is quenched and new fluorescence band is formed at $690 \mathrm{~nm}$. Based on NMR measurements it is evident that the studied hydrazones were present in solution in two tautomeric forms. The tautomer's proportionate representation in aprotic solvents (DMF, DMSO, $\mathrm{CH}_{3} \mathrm{CN}$ ) can be reversibly changed by altered irradiation with the wavelength at $465 \mathrm{~nm}$ and $624 \mathrm{~nm}$. In addition to the light-stimulated tautomeric equilibrium shift at the irradiation, $\mathrm{E} \leftrightarrows \mathrm{Z}$ isomerization occurs. The $E$-isomer in these solvents is thermally unstable. The studied hydrazones irradiation in protic solvents $\left(\mathrm{CH}_{3} \mathrm{OH}\right)$ and in non-polar solvents $\left(\mathrm{CHCl}_{3}\right.$ etc. $)$ with low dielectric constant leads exclusively to $\mathrm{Z} \leftrightarrows \mathrm{E}$ photochemical isomerization. Studied hydrazones provide coloured solutions in the presence of fluoride, chloride and acetate ions in DMF. The hydrazones sensitivity in the ions presence depend on the bases ionicity. From the data in Table 4 (detection and quantificaton limits) it is evident, that compounds 3 and 4 are considered to be very good $\mathrm{F}^{-}$ion sensors when compared to the previously published data. Anions decrease the hydrazoform concentration that is reflected in the fluorescence spectra by fluorescence intensity decreasing at $550 \mathrm{~nm}$ and increasing the second tautomer fluorescence intensity at $690 \mathrm{~nm}$. The studied hydrazones in the presence of fluoride ions have the molecular ON/OFF switch properties with the response in the form of colorimetric, fluorescence changes as the "answer" to the stimulus (light). This ON/OFF function corresponds to the reversible change in tautomeric equilibrium.

Supplementary Materials: The following are available online: compound $1 \mathrm{UV}$-Vis spectra change during irradiation $(\lambda=465 \mathrm{~nm})$; Figure S1. Photolysis of compound 2-5 in $\mathrm{CHCl}_{3}$; Figure S2. The photolysis course of compound 1 to 5 in DMF; Figure S3. TBAF effect on UV-Vis spectra in DMF; Figure S4. ${ }^{1} \mathrm{H}$ NMR spectrum (aromatic region) of compound 4 in $\mathrm{CDCl}_{3}$; Figure S5. ${ }^{1} \mathrm{H}$ NMR spectrum (aromatic region) of compound 4 in DMSO-D 6 ; Figure S6.

Author Contributions: J.D. and K.C. performed the spectroscopic and titration experiments; M.H. and P.T. synthesized and characterized isatin hydrazones; J.F. performed the NMR experiments and interpreted the data related to NMR experiments; G.A. performed HRMS experiments and measurements; R.S. performed HPLC measurements; J.D. and A.G. wrote the paper and, together with M.C., designed the experiments and interpreted the data.

Funding: This research was funded by Comenius University Science Park, ITMS: 26240220086. 
Conflicts of Interest: The authors declare no conflict of interest. The founding sponsors had no role in the design of the study; in the collection, analyses, or interpretation of data; in the writing of the manuscript, and in the decision to publish the results.

\section{References}

1. Cigáň, M.; Gáplovský, M.; Jakusová, K.; Donovalová, J.; Horváth, M.; Filo, J.; Gáplovský, A. Isatin N2-diphenylhydrazones: New easily synthesized Vis-Vis molecular photoswitches. RSC Adv. 2015, 5, 62449-62459. [CrossRef]

2. Cigáň, M.; Jakusovsá, K.; Gáplovský, M.; Donovalová, J.; Filo, J.; Gáplovský, A. Isatin phenylhydrazones: Anion enhanced photochromic behavior. Photochem. Photobiol. Sci. 2015, 14, 2064-2073. [CrossRef] [PubMed]

3. Horváth, M.; Cigáň, M.; Filo, J.; Jakusová, K.; Gáplovský, M.; Šandrik, R.; Gáplovský, A. Isatin pentafluorophenylhydrazones: Interesting conformational change during anion sensing. RSC Adv. 2016, 6, 109742-109750. [CrossRef]

4. Tian, H.; Xu, T.; Zhao, Y.; Chen, K. Two-path photo-induced electron transfer in naphthalimide-based model compound. J. Chem. Soc. Perkin Trans. 1999, 2, 545-550. [CrossRef]

5. De Silva, A.P.; Rice, T.E. A small supramolecular system which emulates the unidirectional, path-selective photoinduced electron transfer (PET) of the bacterial photosynthetic reaction centre (PRC). Chem. Commun. 1999, 163-164. [CrossRef]

6. Liu, X.L.; Du, X.J.; Dai, C.G.; Song, Q.H. Ratiometric Two-Photon Fluorescent Probes for Mitochondrial Hydrogen Sulfide in Living Cells. J. Org. Chem. 2014, 79, 9481-9489. [CrossRef] [PubMed]

7. Manjare, S.T.; Kim, Y.; Churchill, D.G. Selenium- and Tellurium-Containing Fluorescent Molecular Probes for the Detection of Biologically Important Analytes. Acc. Chem. Res. 2014, 47, 2985-2988. [CrossRef]

8. Wu, W.; Guo, H.; Wu, W.; Ji, S.; Zhao, J. Long-Lived Room Temperature Deep-Red/Near-IR Emissive Intraligand Triplet Excited State (3IL) of Naphthalimide in Cyclometalated Platinum(II) Complexes and Its Application in Upconversion. Inorg. Chem. 2011, 50, 11446-11460. [CrossRef] [PubMed]

9. Xiao, P.; Dumur, F.; Graff, B.; Gigmes, D.; Fouassier, J.P.; Lalevée, J. Blue Light Sensitive Dyes for Various Photopolymerization Reactions: Naphthalimide and Naphthalic Anhydride Derivatives. Macromolecules 2014, 47, 601-608. [CrossRef]

10. Li, X.; Zhou, Y.; Zhang, Y.; Son, Y.A. Investigation of a Naphthalimide Based OH- Sensor with Quinoline Attached. Mol. Cryst. Liq. Cryst. 2015, 622, 84-93. [CrossRef]

11. Wang, C.; Feng, S.; Feng, S.; Wu, L.; Yan, S.; Zhong, C.; Guo, P.; Huang, R.; Weng, X.; Zhou, X. A new fluorescent turn-on probe for highly sensitive and selective detection of sulfite and bisulfite. Sens. Actuators B 2014, 190, 792-799. [CrossRef]

12. Wang, P.; Liu, J.; Lv, X.; Liu, Y.; Zhao, Y.; Guo, W. A Naphthalimide-Based Glyoxal Hydrazone for Selective Fluorescence Turn-On Sensing of Cys and Hcy. Org. Lett. 2012, 14, 520-523. [CrossRef] [PubMed]

13. Jiang, J.; Jiang, H.; Liu, W.; Tang, X.; Zhou, X.; Liu, W.; Liu, R. A Colorimetric and Ratiometric Fluorescent Probe for Palladium. Org. Lett. 2011, 13, 4922-4925. [CrossRef] [PubMed]

14. Spangler, C.W. Recent development in the design of organic materials for optical power limiting. J. Mater. Chem. 1999, 9, 2013-2020. [CrossRef]

15. Zhang, G.F.; Aldred, M.P.; Gong, W.L.; Li, C.; Zhu, M.Q. Utilising tetraphenylethene as a dual activator for intramolecular charge transfer and aggregation induced emission. Chem. Commun. 2012, 48, 7711-7713. [CrossRef] [PubMed]

16. Tian, Y.; Su, F.; Weber, W.; Nandakumar, V.; Shumway, B.R.; Jin, Y.; Zhou, X.; Holl, M.R.; Johnson, R.H.; Meldrum, D.R. A series of naphthalimide derivatives as intra and extracellular pH sensors. Biomaterials 2010, 31, 7411-7422. [CrossRef] [PubMed]

17. Gan, J.; Tian, H.; Wang, Z.; Chen, K.; Hill, J.; Lane, P.A.; Rahn, M.D.; Fox, A.M.; Bradley, D.D.C. Synthesis and luminescence properties of novel ferrocene-naphthalimides dyads. J. Organomet. Chem. 2002, 645, 168-175. [CrossRef]

18. Guha, S.; Saha, S. Fluoride Ion Sensing by an Anion- $\pi$ Interaction. J. Am. Chem. Soc. 2010, 132, $17674-17677$. [CrossRef] 
19. Cheshmedzhieva, D.; Ivanova, P.; Stoyanov, S.; Tasheva, D.; Dimitrova, M.; Ivanov, I.; Illieva, S. Experimental and theoretical study on the absorption and fluorescence properties of substituted aryl hydrazones of 1,8-naphthalimide. Phys. Chem. Chem. Phys. 2011, 13, 18530-18538. [CrossRef]

20. Zhang, W.; Xu, Y.; Hanif, M.; Zhang, S.; Zhou, J.; Hu, D.; Xie, D.; Ma, Y. Enhancing Fluorescence of Naphthalimide Derivatives by Suppressing the Intersystem Crossing. J. Phys. Chem. C 2017, 121, 23218-23223. [CrossRef]

21. Tarai, A.; Baruah, J.B. Changing $\pi$-Interactions and Conformational Adjustments of $N$-(Isonicotinylhydrazide)-1,8-naphthalimide by Hydration and Complexation Affect Photophysical Properties. Cryst. Growth Des. 2018, 18, 456-465. [CrossRef]

22. Gu, P.; Xu, X.; Zhou, F.; Zhao, T.; Ye, G.; Liu, G.; Xu, Q.; Ge, J.; Xu, Q.; Lu, J. Study of Linear and Nonlinear Optical Properties of Four Derivatives of Substituted Aryl Hydrazones of 1,8-Naphthalimide. Chin. J. Chem. 2014, 32, 205-211. [CrossRef]

23. Tisovský, P.; Šandrik, R.; Horváth, M.; Donovalová, J.; Gáplovský, M.; Jakusová, K.; Cigáň, M.; Sokolík, R.; Gáplovský, A. Effect of structure on charge distribution in the Isatin Anions in aprotic environment: Spectral study. Molecules 2017, 22, 1961. [CrossRef] [PubMed]

24. Mati, S.S.; Chall, S.; Bhattacharya, S.C. Aggregation-Induced Fabrication of Fluorescent Organic Nanorings: Selective Biosensing of Cysteine and Application to Molecular Logic Gate. Langmuir 2015, 31, 5025-5032. [CrossRef]

25. Saha, S.; Samanta, A. Influence of the Structure of the Amino Group and Polarity of the Medium on the Photophysical Behavior of 4-Amino-1,8-naphthalimide Derivatives. J. Phys. Chem. A 2002, 106, 4763-4771. [CrossRef]

26. Pike, S.J.; Hutchinson, J.J.; Hunter, C.A. H-Bond Acceptor Parameters for Anions. J. Am. Chem. Soc. 2017, 139, 6700-6706. [CrossRef] [PubMed]

27. Chereddy, N.R.; Nagaraju, P.; Raju, M.V.N.; Saranraj, K.; Thennarasu, S.; Rao, V.J. A two fluorophore embedded probe for collective and ratiometric detection of $\mathrm{Hg}^{2+}$ and $\mathrm{F}^{-}$ions. Dyes Pigment. 2015, 112, 201-209. [CrossRef]

Sample Availability: Samples of the compounds 1-5 are available from the authors.

(c) 2019 by the authors. Licensee MDPI, Basel, Switzerland. This article is an open access article distributed under the terms and conditions of the Creative Commons Attribution (CC BY) license (http:/ / creativecommons.org/licenses/by/4.0/). 